\title{
Hydraulic Function Analysis of Conifer Xylem Based on a Model Incorporating Tracheids, Bordered Pits, and Cross-Field Pits
}

\author{
Wen Qu ${ }^{1,2}$, Chunmei Yang ${ }^{1,2, *}$, Jiawei Zhang ${ }^{1,2}$, Yan Ma ${ }^{1,2}$, Xinchi Tian ${ }^{1,2}$, Shuai Zhao ${ }^{1,2}$ and Wenji Yu ${ }^{3, *}$ \\ 1 College of Mechanical and Electrical Engineering, Northeast Forestry University, Harbin 150040, China; \\ qwnefu@126.com (W.Q.); zjw@nefu.edu.cn (J.Z.); myan_vip@126.com (Y.M.); xinchitian@126.com (X.T.); \\ zshuai321@126.com (S.Z.) \\ 2 National Forestry Grassland Artificial Intelligence and Equipment Engineering Technology Research Center, \\ Northeast Forestry University, Harbin 150040, China \\ 3 Research Institute of Wood Industry, Chinese Academy of Forestry, Beijing 100864, China \\ * Correspondence: ycmnefu@126.com (C.Y.); yuwenji@caf.ac.cn (W.Y.)
}

check for updates

Citation: Qu, W.; Yang, C.; Zhang, J.; Ma, Y.; Tian, X.; Zhao, S.; Yu, W. Hydraulic Function Analysis of Conifer Xylem Based on a Model Incorporating Tracheids, Bordered Pits, and Cross-Field Pits. Forests 2022, 13, 171. https://doi.org/ 10.3390/f13020171

Academic Editors: Edward Roszyk and Magdalena Broda

Received: 22 December 2021

Accepted: 20 January 2022

Published: 22 January 2022

Publisher's Note: MDPI stays neutral with regard to jurisdictional claims in published maps and institutional affiliations.

Copyright: (c) 2022 by the authors. Licensee MDPI, Basel, Switzerland. This article is an open access article distributed under the terms and conditions of the Creative Commons Attribution (CC BY) license (https:// creativecommons.org/licenses/by/ $4.0 /)$.

\begin{abstract}
Wood has a highly complex and anisotropic structure. Its xylem characteristics are key in determining the hydraulic properties of plants to transport water efficiently and safely, as well as the permeability in the process of wood impregnation modification. Previous studies on the relationship between the xylem structure and hydraulic conductivity of conifer have mainly focused on tracheids and bordered pits, with only a few focusing on the conduction model of cross-field pits which connect tracheids and rays. This study takes the xylem structure of conifer as an example, drawing an analogy between water flow under tension and electric current, and extends the model to the tissue scale, including cross-field pits by establishing isometric scaling. The structure parameters were collected by scanning electron microscopy and transmission electron microscopy. The improved model can quantify the important hydraulic functional characteristics of xylem only by measuring the more easily obtained tracheid section size. Then, this model was applied to quantify the relationship between the xylem anatomical structure and hydraulic properties in the pine (Pinus sylvestris L. var. mongholica Litv.) and the spruce (Picea koraiensis Nakai), and also to evaluate the effects of the number and size of cross-field pits on xylem conduction. The results showed that the growth ring conduction value of the pine was more than twice that of the spruce for the two tree species with similar growth widths in this study. The tracheid wall resistance of the pine reflected the result of the interaction of the size and number of cross-field pits, in comparison, the wall resistance of the spruce was more sensitive to the number of cross-field pits. Finally, the calculation output of the new model was cross-validated with the literature, which verified the accuracy and effectiveness of the model. This study provides an effective and complete solution for xylem conductivity measurement and the study of wood ecophysiological diversity and processing.
\end{abstract}

Keywords: conifer; cross-field pits; bordered pits; hydraulic properties; flow resistance; model

\section{Introduction}

Wood has a highly complex and anisotropic structure characterized by different xylem structures that result in different hydraulic properties. The xylem of conifers is mainly composed of tracheids and rays. Tracheids account for about $80-93 \%$ of the xylem volume and play an important role in water conduction and mechanical strength. On the contrary, ray cells account for about $7-20 \%$ of the xylem and perform functions of water transportation and nutrient storage [1-4]. The hydraulic characteristics of xylem determine the responses of plant growth to environmental conditions and whether water can effectively and safely be provided to leaves. Xylem structures are also key to determining the permeability of wood during its processing; that is, the treatability of wood is a function of the anatomical 
properties developed under certain growing conditions [5]. Regarding the water conduction model of xylem of conifer, numerous studies have focused on the function of the axial tracheid-bordered pit model, but less is known about the water transport model of crossfield pits connecting axial tracheids and wood rays, which is limited by the complexity of wood as a biological system.

However, it is speculated that differences in the cross-field pit structure of wood rays in many tree species are related to water transport efficiency. Some pine trees (such as Mongolian scotch pine) have good radial flow. In such pine trees, the water flow is thought to be confined to the larger holes between the ray parenchyma cells: it enters the axial tracheids through the cross-field pits, and then enters the adjacent ray parenchyma cells from there. The sapwood of Mongolian scotch pine is generally considered to be easily impregnated, and significant changes can be observed during its treatment [6,7]. Tarmian and Azadfallah have reached a similar conclusion that the radial flow of fluid in wood rays does not occur in isolation [8]. The fluid enters the adjacent axial tracheid system through cross-field pits and then returns to other wood ray cells.

Many scholars have also verified the conduction of wood rays and cross-field pits through experiments. Through experiments on wood impregnation with protective agent, Zimmer found that the easily treatable Scots pine sapwood has more parenchyma cells in the rays. At the same time, a large cross-field pit membrane area was observed in the easily treated sample fraction. [6,9]. Siau showed that the radial flow of some fluids in Sitka spruce is realized by ray parenchyma cells, and that the liquid circulates between the longitudinal tracheids and the ray parenchyma cells through the cross-field pits [10]. Bauch et al. found that the total membrane area of the cross fields and the higher number of ray parenchyma cells in easily treated wood led to a higher conduction area, which can be used as an impregnation pathway [8]. When comparing the treatability of different tree species, it was found that tree species with large cross-field pit areas and many ray parenchyma cells had higher impregnation absorption capacity.

It is now clear that wood rays, once thought to be "underestimating paths" [3], play an important role in the hydraulic regulation of the entire tree. If wood rays and cross-field pits are not considered, then evaluation of the influence of the xylem structure on the hydraulic architecture is not complete.

In studies on the hydraulic characteristics of plants, many scholars have carried out exploratory research by means of numerical simulation, such as in the example of the theoretical framework based on the Hagen-Poiseuille equation [11-15]. The electrical simulation takes the water flow as the current in the circuit and applies it to simulate water transportation in complex systems. Sperry and Hacke applied a mathematical model to gymnosperm tracheids for predicting the conductivity of bordered pits and tracheids [16,17]. Wilson et al. developed a more complex model centered on single tracheids [18]. These models have also been combined using average tracheides characteristics in scaling up to the tissue level. However, in the tissue model of Wilson et al., the rays which cross the tangential layer of tracheids were considered non-conductive, and the wood rays would even seal part of their bordered pits on the radial walls of tracheids, thus affecting the overall resistance of wood samples [19-21]. Sviderskaya I.V. considered the anatomical variability of tracheids in the interannual cycle and built a model of the structure and hydraulic characteristics of tracheids during the growth ring cycle, but did not analyze the conduction of wood rays and cross-field pits between tracheids [22]. However, these models provide a reference for the construction of the model in this article, at least to a certain extent.

To summarize, although many scholars have demonstrated that cross-field pits are a path for liquid transmission, considerably significant results have been obtained, using many of the methods mentioned above, regarding the structure and hydraulic properties of both single tracheids and groups of tracheids. However, none of the hydraulic models developed to date comprehensively consider variations in tracheid size and the anatomical parameters of the cross-field pits connecting tracheid and ray parenchyma cells. In this 
paper, a comprehensive hydraulic conduction model that includes tracheids, bordered pits and cross-field pits is proposed for an improved analysis of the relationship between the xylem structure and flow characteristics on the tissue scale. The proposed method was applied to quantify the relationship between the structure and hydraulic characteristics of two representative coniferous species, the pine (Pinus sylvestris L. var. mongholica Litv.) and the spruce (Picea koraiensis Nakai) [23-25], and the reasons for the different conductivity of different tree species are analyzed from the perspective of theoretical models. Finally, the calculation output of the new model was cross-validated with data in the literature for verification and analysis. As the inputs of the model and the geometry of the hydraulic components of the xylem have been parameterized, with appropriate ultrastructure and microstructure data, the proposed model can be generally applied to the analysis of hydraulic functions of the xylem of conifers.

\section{Materials and Methods}

\subsection{Theoretical Approach}

The anatomical structure of the xylem has an important influence on hydraulic conduction [26]. When the overall structure of the xylem is regarded as a network, it can be viewed as a highly complex and closely connected system on all scales, from a single tracheid and xylem tissue to the overall structure of plants, as shown in Figure 1. The water in plants moves under tension (negative hydrostatic pressure). If the water flows through the analogous plant current in the circuit, then, based on Ohm's law, the anatomical components of the connecting xylem have an important influence on the quantitative and accurate evaluation of the xylem hydraulic characteristics [27]. Our model is consistent with the generally accepted theory of cohesive tension: that is, water flows through a network of tracheids of different sizes under tension $[18,20,28]$. The tracheid is regarded as a circuit with a total resistance of $R_{t o t}$ in the model. Its flow $Q(Q=\Delta P / R)$ is equal to the current $(I)$, and the pressure drop $(\Delta P)$ is equal to the voltage drop $V(I=V / R)$.

(a)

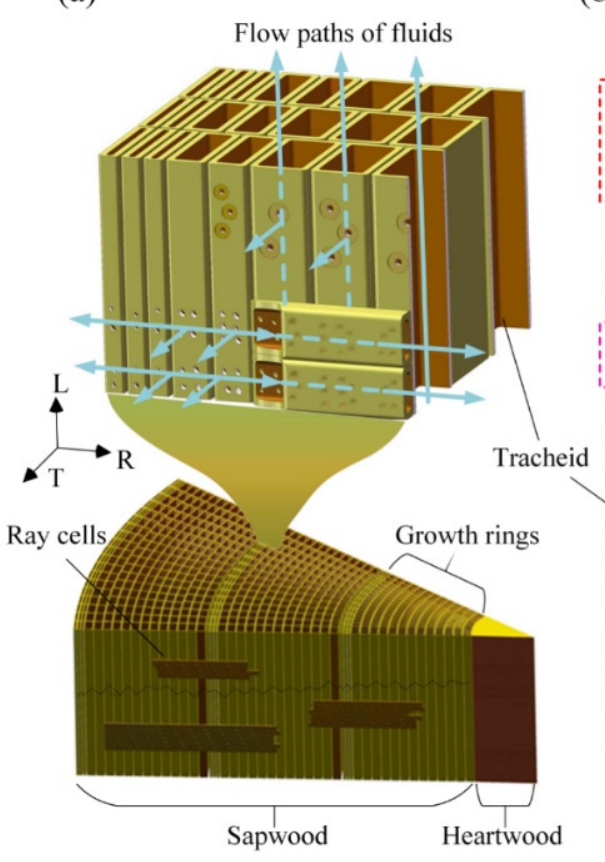

(b)
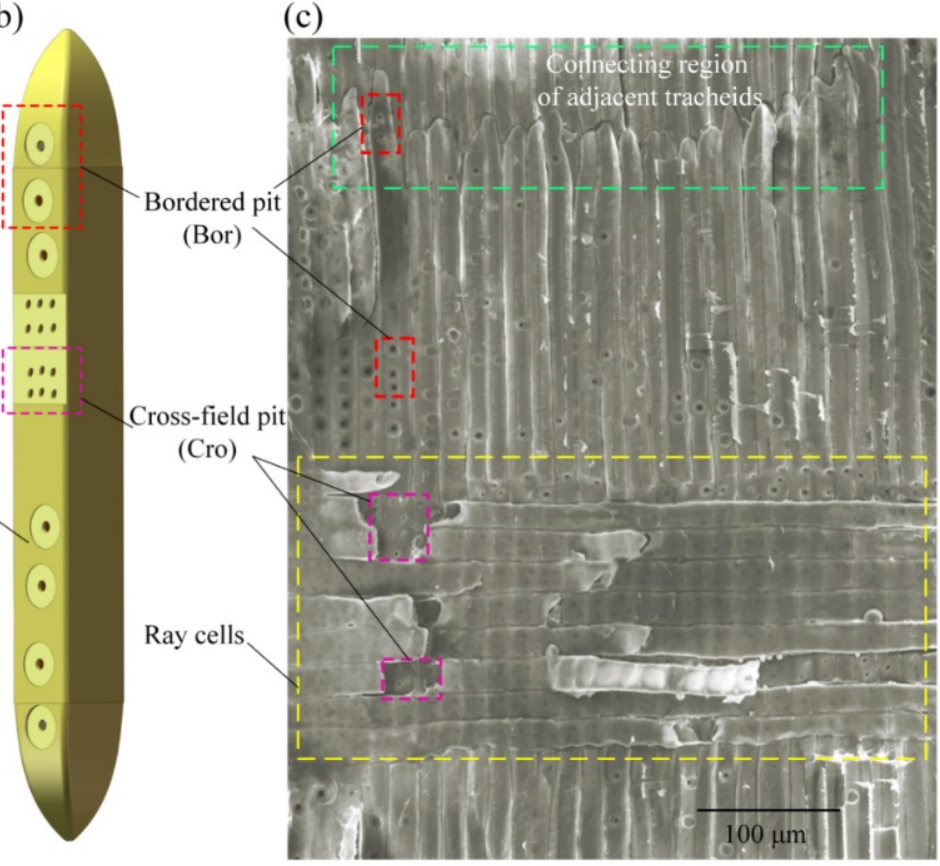

Figure 1. The diagram of the xylem structure of conifer. (a) Three-dimensional view of a portion of xylem sapwood, including earlywood, latewood tracheid and rays; (b) a complete tracheid model containing the bordered pits and cross-field pits and the section view showing the tracheid lumen; (c) The scanning electron microscopy (SEM) micrographs of longitudinal tracheids and wood ray cells on the radial section of the conifer xylem. 
Water flows from one tracheid to adjacent tracheids, the total flow resistance $\left(R_{t o t}\right)$ of a single tracheid is the sum of the resistance of the lumen $\left(R_{l u m}\right)$ and the resistance of the wall $\left(R_{\text {wall }}\right)$ in series $[11,15,22]$ :

$$
R_{\text {tot }}=R_{\text {wall }}+R_{\text {lum }}
$$

Lumen resistance $R_{l u m}$ is calculated according to the Hagen-Poiseuille equation [29]:

$$
R_{l u m}=\frac{128 \zeta \mu H}{\pi D_{t r}^{4}}
$$

where the proportion of tracheid overlap $\zeta=0.5[14,15] . H$ is tracheid length, $\mu$ is the viscosity of the water flowing through the tracheids, which varies with the solute in the water and environmental factors such as temperature. Here, we use the viscosity value of water at $20^{\circ} \mathrm{C}$ as $1.002 \times 10^{-9} \mathrm{~kg} \mathrm{~s}^{-1} \mu \mathrm{m}^{-1}$ in all calculations [22,26,30], and the hydraulic diameter $D_{t r}$ of the rectangular lumen section of conifer can be calculated as:

$$
D_{t r}=\frac{2 L_{t r} \times T_{t r}}{L_{t r}+T_{t r}}
$$

where $L_{t r}$ and $T_{t r}$ are the radial and tangential lumen diameters, respectively. Substituting Equation (3) into Equation (2) gives:

$$
R_{\text {lum }}=\frac{8 \zeta \mu H\left(L_{t r}+T_{t r}\right)^{4}}{\pi L_{t r} T_{t r}^{4}}
$$

In the tissue model containing rays and tracheids, ray parenchyma cells are connected to the axial tracheid by cross-field pits (mostly single or semi-bordered pits), while there is obvious hydraulic resistance for water flowing from axial tracheids to ray parenchyma cells. These pit types are similar to the type of bordered pits that connect adjacent axial tracheids, which allows water to flow, so the total flow wall resistance can be calculated as:

$$
R_{\text {wall }}=2 \times \frac{1}{\sum_{i=1}^{n} \frac{1}{R_{\text {pit }}}}=2 \frac{R_{\text {pit }}}{N_{\text {pit }}}
$$

As for $R_{\text {pit }}$, a research model of previous researchers is shown in Figure 2a. In their model, the wall resistance only includes the flow resistance caused by the components of the bordered pits, ignoring the cross-field pit resistance. Our study complements this part by including the resistance $R_{\text {Bor }}$ from bordered pits and the resistance $R_{C r o}$ from cross-field pits (Figure $2 b-d$ ).

The flow resistance of water flowing through cross-field pits and bordered pits is parallel, but the structural types and quantities of the two pits are different (as shown in Figure 3c), so the resistance values are also different. Therefore, Formula (5) is transformed into the following form:

$$
R_{\text {wall }}=2 \times \frac{1}{\sum_{i=1}^{N_{\text {Bor }}} \frac{1}{R_{\text {Bor }}}+\sum_{i=1}^{N_{\text {Cro }}} \frac{1}{R_{\text {Cro }}}}=2 \frac{R_{\text {Bor }} R_{\text {Cro }}}{N_{\text {Bor }} R_{\text {Cro }}+N_{C r o} R_{\text {Bor }}}
$$

where $N_{B o r}$ and $N_{C r o}$ are the number of bordered pits and cross-field pits on a single tracheid, respectively, which are obtained from the calculation of the density $(\alpha, \beta$, Table 1$)$ of two pits on the unit radial wall area of tracheids in the electron microscope images and verified with data in the relevant literature.

$$
\begin{aligned}
& N_{\text {Bor }}=H \times L_{t r} \times \alpha \\
& N_{C r o}=H \times L_{t r} \times \beta
\end{aligned}
$$




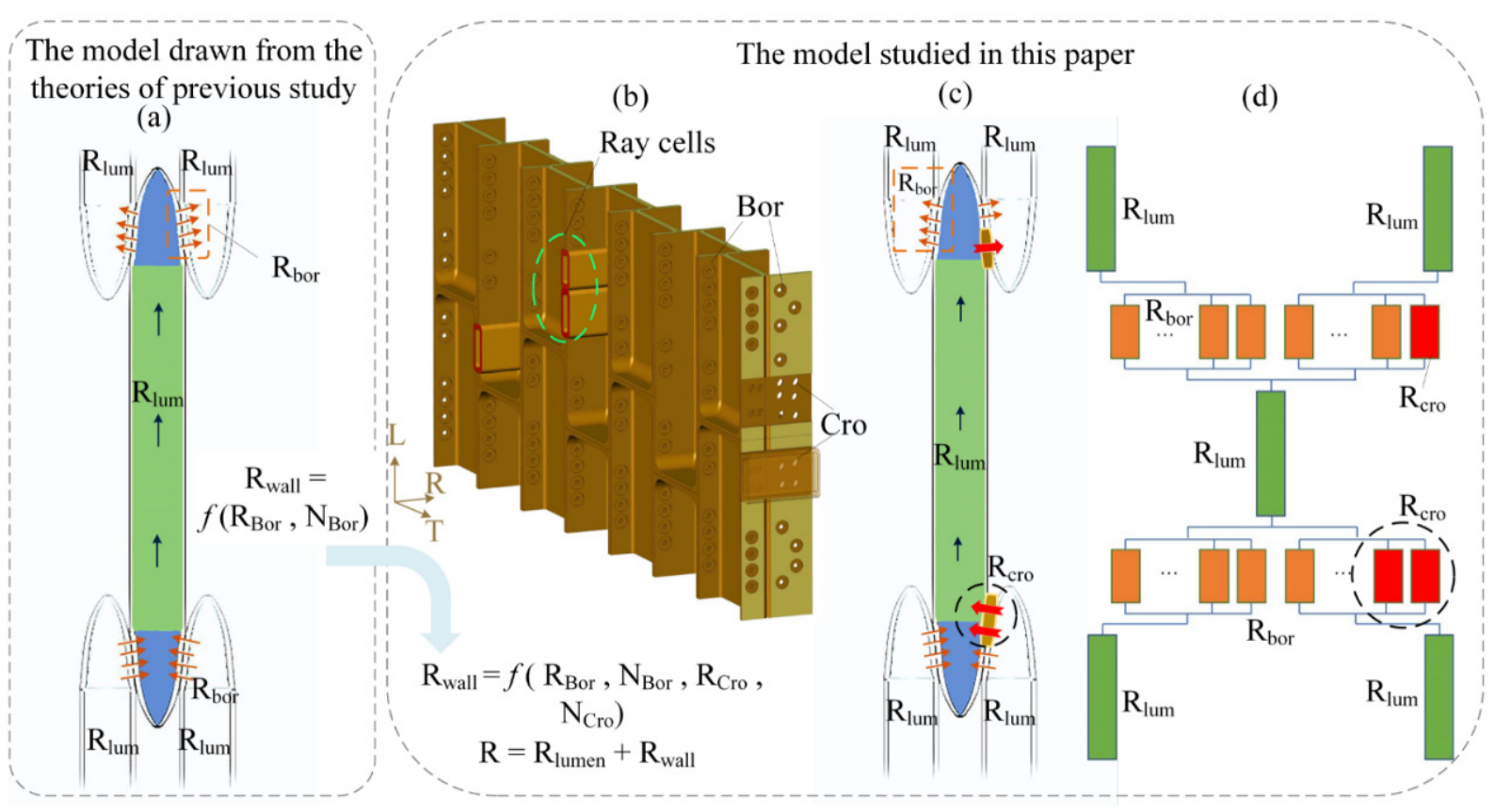

Figure 2. Schematic diagram of hydraulic model at tissue scale. (a) Water flow through the lumen and the wall of a tracheid and corresponding resistances drawn from a previous study; the variables that constitute the wall resistance are simply the size and number of bordered pits; (b) three-dimensional diagram of the xylem tangential plane. Compared with previous studies, the cross-field pits in the area where axial tracheids and ray parenchyma intersect were added. The variable of wall resistance is composed of the size and number of bordered pits and the size and number of cross-field pits; (c) compared with Figure 2a, the annotation of cross-field pits is added in this model; (d) the different components of the total resistance of a single tracheid and the connections to its neighbors. The horizontal orange and red components represent the two types of pit resistance that make up the wall resistance, namely bordered pits (orange) and cross-field pits (red), and the connections are parallel. The vertical green components represent the lumen resistance in series with the wall resistance.

In this work, $R_{\text {Bor }}$ was determined following Hacke and Sviderskaya $[15,22]$; they calculated the resistance of bordered pits as a function of margo porosity number $\left(N_{p o}\right)$, margo equivalent aperture $\left(D_{p o}\right)$, diameter of aperture $\left(D_{a}\right)$, and channel length $\left(t_{a p}\right)$ (Figure 3a):

$$
R_{\text {bor }}=2 R_{\text {aperture }}+2 R_{\text {cannal }}+R_{\text {membrane }}=2 \frac{24 \mu}{D_{a}^{3}}+2 \frac{128 t_{\text {ap }} \mu}{\pi D_{a}^{4}}+\frac{24 \mu \eta}{n_{p o} D_{p o}^{3}} f(\varepsilon)
$$

where $f(\varepsilon)$ represents a correction function that takes into account the interaction between the porosity $\varepsilon$ in margo and the water flow through the margo pores. In this paper, the value was $\eta$ according to experimental measurements and references. $\eta$ is to adjust the difference between the experimental data and the theoretical model of fluid flow with bordered pits. In Equation (9), the membrane resistance is modified by a constant to allow for changes in membrane resistance. Realizing that some membranes may be obstructed by pectin and amorphous compounds, this constant (1-1000) provides more flexibility in explaining the conduction function of tracheids [18,31]. Our default value of 20 was based on the research object and literature estimates. 


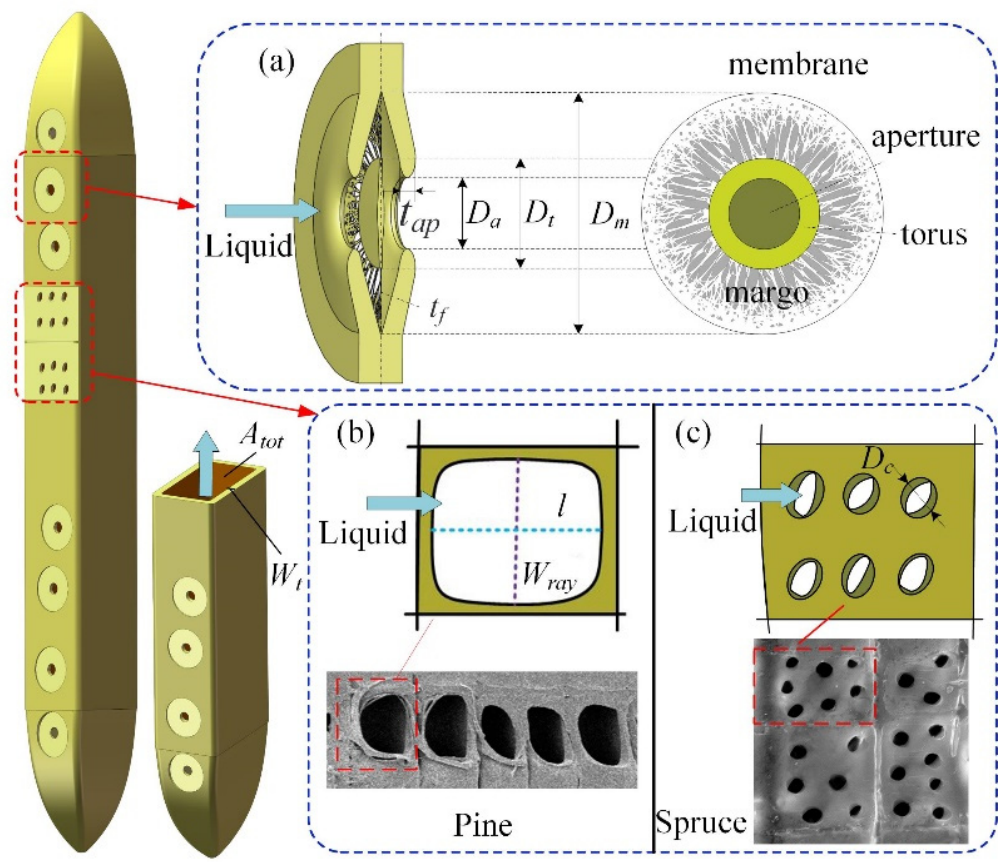

Figure 3. Dimension parameters for calculating the resistance of bordered pits and cross-field pits. (a) Parameters used to calculate bordered pit resistance. Parameters used to calculate cross-field pit resistance of (b) pine (Pinus sylvestris L. var. mongholica Litv.) and (c) spruce (Picea koraiensis Nakai), where the cross-field pit membranes of both have been removed.

The number of pores in the margo $\left(N_{p o}\right)$ is calculated following Sviderskaya [22] as:

$$
N_{p o}=\frac{D_{m a}^{2}}{\left(0.63 D_{p o}+t_{f}\right)^{2}}=\frac{D_{m}^{2}-D_{t}^{2}}{\left(0.63 D_{p o}+t_{f}\right)^{2}}
$$

The cross-field pit membrane is very thin $[2,3,14]$. Calculating the hydraulic conductivity of a single pit refers to calculating the hydraulic resistance $R_{p}$ of a circular hole with a diameter of $D_{p}$ from an infinite thin plate:

$$
R_{p}=24 \mu / D_{p}^{3}
$$

The cross-field pits are mostly single pits or single-border pits, and single-pit resistance can be considered as a combination of the pit canal and cross-field pit membrane. Single pit resistance can be considered as pit resistance $\left(R_{\text {canal-C }}\right)$, and cross-field pit membrane resistance $\left(R_{m e m-C}\right)$ can be calculated in series:

$$
R_{\text {Cro }}=2 R_{\text {canal }-C}+R_{\text {mem-C }}=2 \times \frac{128 t_{\text {ray }} \times \mu}{\pi D_{\text {Cro }}^{4}}+\frac{24 \mu \sigma}{D_{\text {Cro }}^{3}}
$$

where the channel length is the wall thickness in the cross-field pits, and $t_{\text {ray }}=W_{t}=-80 / 7$ $L_{t r}+4$ (Table 1), $\sigma$ is the correction coefficient set according to the opening condition and surface morphology of the cross-field pit membrane [22].

$D_{C r o}$ is the equivalent diameter of the cross-field pit, and the measurement method is shown in Figure 3b. The cross-field pits of the pine are the window-pane type. Generally, there is only one pit in each cross field, which is approximately rectangular. One side of the boundary is the lumen width $L_{t r}$, and the other side is approximately the inner diameter of ray parenchyma cells, which is set as $W_{\text {ray }}$. Quantitative characters were measured according to scale bars or through the scanning electron microscopy (SEM) measurement tool. The size of pits was consistently measured at the broadest point. Then, 
according to Formula (3), the hydraulic diameter $D_{C r o-M}$ of the cross-field pit of the pine is approximately:

$$
D_{C r o-M}=2 \times \frac{L_{t r} \times W_{\text {ray }}}{L_{t r}+W_{\text {ray }}}
$$

For the cross-field pits of the spruce, their apertures are elliptical, and the aperture width is equivalent to that of the pit border. There are generally three to six pits in each cross field, with two or seven occurring occasionally. According to a large number of measurements by scanning electron microscopy (SEM) and transmission electron microscopy (TEM) in this paper, it was found that the size and number of cross-field pits of the two species had a certain correlation with the radial diameter $L_{t r}$ of the tracheids, and some parameters, such as the width of ray parenchyma cells, had a certain approximation. In this paper, the calculated statistical rules and approximate mean values are recorded in Table 1.

$$
R_{C r o}=\frac{16 t_{\text {ray }} \mu\left(L_{t r}+W_{\text {ray }}\right)^{4}}{\pi L_{t r}{ }^{4} W_{\text {ray }}{ }^{4}}+\frac{3 \mu \sigma\left(L_{t r}+W_{\text {ray }}\right)^{3}}{L_{t r}{ }^{3} W_{\text {ray }}{ }^{3}}
$$

As for the research object in this paper, according to electron microscope observations, the surface of the cross-field pit membrane was covered by abundant amorphous material, no obvious openings were visible, the surface structure was not clear, and, occasionally, there were microfibrils arranged on the surface of the pit membrane. Therefore, we chose the upper limit of the correction coefficient as $\sigma=1000$. These values ( $\sigma$ and $\eta$ ) preserved the ratio of the membrane to the pit resistances at above $60 \%$, which is basically consistent with the literature results $[18,19,32]$.

We use conductance $(K)$ to describe the ease with which water passes through conductive cells. It is the reciprocal of resistance $(R)$ :

$$
K=\frac{1}{R}
$$

A more standard normalization is to calculate the specific conductivity per tracheid $\left(K_{s c}\right)$, which is obtained by normalizing $(K)$ by tracheid length and the total area $\left(A_{\text {tot }}\right.$, both the cross-sectional area of the cell wall and the lumen), and it is calculated in the model by dividing tracheid length $(H)$ by the product of the $A_{t o t}$ and total resistance $\left(R_{t o t}\right.$, Formula (1)) [18].

$$
K_{s c}=\frac{H}{R_{t o t} A_{t o t}}
$$

Since the pits mainly connect the adjacent tracheids in the tangential direction for water conduction (Figure 1), they can be approximately regarded as a group of isolated parallel hydraulic resistance $\left(R_{i}\right)$ in the growth ring (radial) [22]. Therefore, the sum of the hydraulic conductance $\left(K_{i}\right)$ of all tracheids in a ring cycle equals the total conductance $\left(K_{\text {ring }}\right)$ of the ring:

$$
K_{\text {ring }}=\sum_{i=1}^{n} K_{i}=\frac{1}{\sum_{i=1}^{n} \frac{1}{R_{i}}}
$$

\subsection{Material}

In this study, branches of two representative coniferous species were selected as wood samples. One was the spruce (Picea koraiensis Nakai), with piceoid-type cross-field pits. In previous studies, it has been demonstrated that this species has poor permeability, so considerable research has been devoted to improving the drying and protection of its wood $[24,25]$. The other species was the pine (Pinus sylvestris L. var. mongholica Litv.) with window-pane-type cross-field pits, which has better permeability and radial conductivity. The ultrastructures of the two wood samples were measured by scanning electron microscopy and transmission electron microscopy. The two wood samples were collected from trees that were about 5 years old from the forest farm of Northeast Forestry University 
in Harbin, Heilongjiang Province, China, and fresh wood samples were collected from a part of the tree within 1-1.8 $\mathrm{m}$ from the ground.

TEM samples were prepared by ultra-microtome and softened (7 days) by soaking in a $50 \%$ alcohol solution. The softened samples were dehydrated in $50 \%, 70 \%, 80 \%$ and $95 \%$ alcohol solution for half an hour, and then dehydrated twice with anhydrous ethanol. After the dehydration, ethanol in the sample was replaced with acetone, first with a solution of ethanol: acetone $=1: 1(\mathrm{vol} / \mathrm{vol})$, and then with pure acetone twice (each of these processes is $30 \mathrm{~min}$ ) [26]. Then, we used low-viscosity epoxy resin to fix and transfer the sample to the embedding plate and number it. Finally, it was sliced after polymerization in an oven at $60^{\circ} \mathrm{C}$ for $24 \mathrm{~h}$. In this study, the ultra-microtome (Leica, Germany, 1/UC7 \FC7) was used for slices with a thickness of $70 \mathrm{~nm}$. In order to improve the clarity of the final captured image, $2 \%$ uranyl acetate was used to stain the slices ( $30 \mathrm{~min})$, and then they were lead-stained for $5 \mathrm{~min}$ to complete the preparation of the TEM samples. The prepared samples were observed under transmission electron microscope (JEM1230, JEOL Co., Ltd., Tokyo, Japan). The acceleration voltage was $80 \mathrm{kV}$, and the magnification was $1 \mathrm{~K} \sim 400 \mathrm{~K}$.

Regarding the sample preparation of the SEM, in order to obtain a complete pit membrane structure, some slices were obtained by splitting and cutting along the radial direction. Information on the wood rays and cross-field pits was obtained from the radial and tangential slices, respectively. To accurately determine the distribution (density) and size of the bordered pits and cross-field pits, it is necessary to examine both earlywood and latewood on both sides of a growth ring boundary. In each growth ring, the part near the pith was earlywood formed early in the growth season, with thin walls, larger tracheids and lighter colors. The part close to the bark is latewood, with a small lumen diameter, a thick wall and a dark wood color. In the samples selected in this study, the growth rings of the pine were obvious, and latewood accounted for about $1 / 3$ of the growth rings, with 3-7 rounds per centimeter, and the earlywood to latewood changed slightly to abruptly. The spruce had obvious growth rings and uniform width, 3-4 rounds per centimeter, gradually changing from earlywood to latewood, and the latewood zones between the growth rings had a darker colour. In addition, in order to prevent deflection changes in the composition and structure of the pit membrane, which could have been caused by the relatively high interfacial tension between the air and water during the drying process, the wood sections were placed in organic solutions characterized by low surface tension (such as ethanol, acetone, etc., the dehydration method was consistent with that of TEM, and different concentrations of ethanol were used for gradual replacement), so as to preserve the wood tissue in its original state as much as possible. The samples were coated with vacuum sputtering apparatus (Quorum Q150TS plus) and observed with scanning electron microscope (FEI Apreos) under $2 \mathrm{kV}-5 \mathrm{kV}$.

\section{Results}

\subsection{Xylem Anatomy of Pinus sylvestris L. var. mongholica Litv. and Picea koraiensis Nakai}

We examined the microscopic morphology of a number of axial tracheids and ray parenchyma cells, and the cross-field pits between them, from pine (Pinus sylvestris L. var. mongholica Litv.) and spruce (Picea koraiensis Nakai). In this study, we measured the structural morphology (cross section, radial section and tangential section) of each interface of the pine and spruce by SEM and TEM, accumulated more than 30 sample tables, and obtained more than 100 groups of effective tracheids and their pit structures (including bordered pits and cross-field pits), which were used to complete the statistics of the structural information of tracheid-pits of two tree species. Figure 4 is the anatomical structure of the stem of the pine, with window-pane-type cross-field pits. Figure 5 shows the structural details of the stem of the spruce, with piceoid-type cross-field pits. 

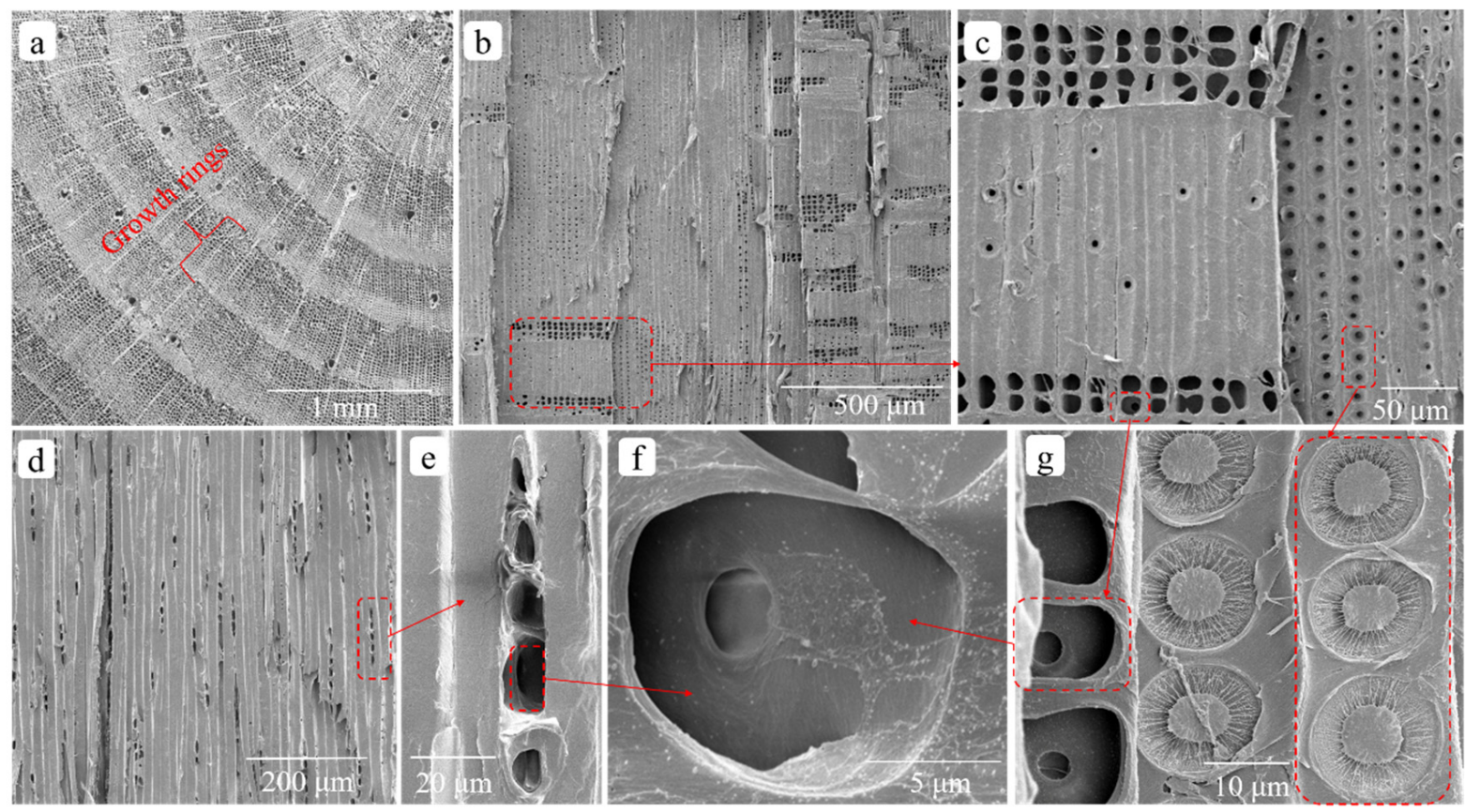

Figure 4. Anatomical structure of the stem of the pine (Pinus sylvestris L. var. mongholica Litv.). (a) Cross section showing the growth ring structure: the upper right corner is wood pith, and the radial white lines from the pith are wood rays; (b) radial section showing longitudinal tracheids and bordered pits, cross fields formed by the intersection of radial parenchyma cells and axial tracheids, and cross-field pits especially connecting axial and transverse tissues; (c) an enlarged view of the area indicated by the box in (b); (d) tangential section showing the cross section of wood rays; (e) the tangential cross section of a set of ray parenchyma cells, in which the framed part is a window pane cross-field pit on the inner wall of the parenchyma cell; (f) an enlarged view of the cross-field pits with the pit membrane removed, through which the bordered pits can be seen; (g) the partial enlarged view of (c), in which there is a window-pane cross-field pit in the horizontal box and three bordered pits in the vertical box. The scale bar is indicated in the figures.

Both species have the same type of bordered pits. Figure 6 shows the bordered pits structure on the radial and transverse tracheid walls; Figure 6a-c were obtained from SEM, and Figure $6 \mathrm{~d}-\mathrm{f}$ were obtained from TEM. It should be emphasized that the cross-sectional view (or tangential view), based on TEM, showing the structural shapes and dimensions of the pit border, and the front view of the pit membrane captured by SEM could not be obtained from the same pit [33-35]. Therefore, it is necessary to integrate information of multiple groups of pit images with similar positions to establish a consistent model. In this study, we collected more than 100 sets of effective pit structures (including bordered pits and cross-field pits), and used them to complete the statistics of the tracheid-pits structural information of two tree species. 

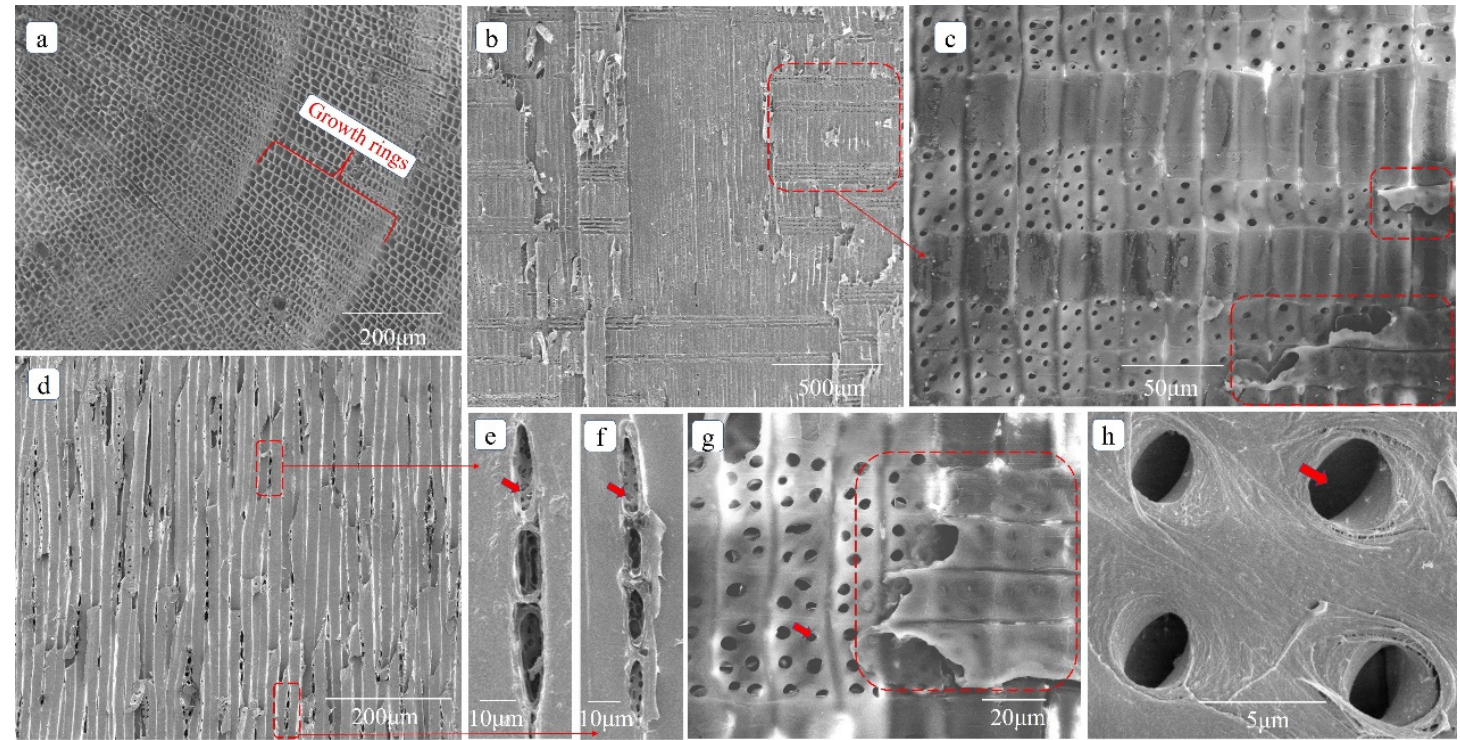

Figure 5. SEM images showing the structural details of the stem of the spruce. (a) Cross section showing the growth ring structure, with an obvious boundary between earlywood and latewood; (b) radial section mainly showing axial tracheids and ray parenchyma cells; (c) an enlarged view of a part of (b), showing the piceoid-type cross-field pits, two to seven per field, and ray parenchyma cells inside the box; (d) tangential section showing the cross section of a tracheid; $(\mathbf{e}, \mathbf{f})$ the enlarged crosssectional views of the two groups of ray parenchyma cells in (d). The arrow points to the piceoid-type cross-field pits on the tangential side of the inner wall of the parenchyma cells; (h) an enlarged view of the piceoid-type cross-field pits; (g) an enlarged view of Figure 5c, with ray parenchyma cells in the box. The scale bar is indicated in the figures.

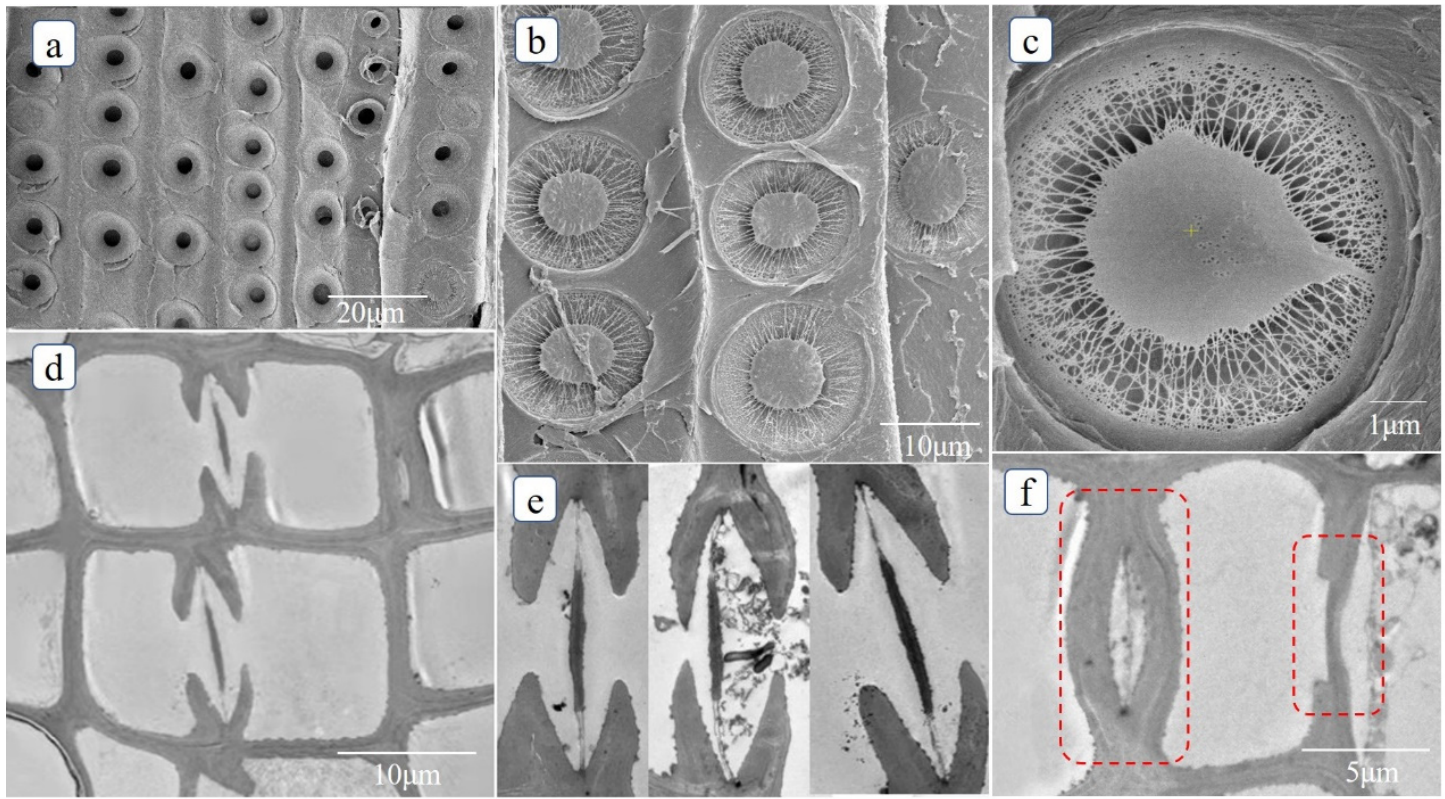

Figure 6. Structures of bordered pits in radial and transverse tracheid walls. (a) Axial tracheids and bordered pits on radial section; $(\mathbf{b}, \mathbf{c})$ enlarged images of different scales of bordered pits; (d) a cross section of some tracheids containing the cross-sectional view of bordered pits; (e) an enlarged view of three adjacent pits; (f) an enlarged view of the cross section of tracheids in which the bordered pits are in the left box and the cross-field pits (single pits) are in the right box. 
Table 1. Model constants, variables, parameters, and numerical range.

\begin{tabular}{|c|c|c|c|c|c|c|}
\hline & \multirow{2}{*}{\multicolumn{2}{|c|}{$\begin{array}{c}\text { Feature } \\
\text { Range (Min-Max) }\end{array}$}} & \multicolumn{2}{|c|}{$\begin{array}{c}\text { The Pine (Pinus sylvestris L. var. } \\
\text { mongholica Litv.) }\end{array}$} & \multicolumn{2}{|c|}{$\begin{array}{c}\text { The Spruce (Picea koraiensis } \\
\text { Nakai) }\end{array}$} \\
\hline & & & Earlywood & Latewood & Earlywood & Latewood \\
\hline \multirow{4}{*}{ 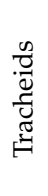 } & $L_{t r}$ & Lumen radial diameter $(\mu \mathrm{m})$ & $2.5-20$ & $15-30$ & $2-11$ & $12.5-25$ \\
\hline & $H$ & Tracheid length (mm) & \multicolumn{2}{|c|}{$2.2-3.3$} & \multicolumn{2}{|c|}{$2.6-3.5$} \\
\hline & \multirow{2}{*}{$W_{t}$} & \multirow{2}{*}{ Wall thickness $(\mu \mathrm{m})$} & \multicolumn{4}{|c|}{$W_{t}=-80 / 7 \times L_{t r}+4($ Figure 7$)$} \\
\hline & & & & & \multicolumn{2}{|c|}{$1.3-4.5$} \\
\hline \multirow{9}{*}{ 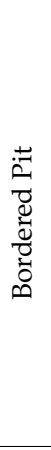 } & $D_{m}$ & Membrane diameter $(\mu \mathrm{m})$ & \multicolumn{4}{|c|}{$0.70 L_{t r}( \pm 0.07)[24,29]$} \\
\hline & $D_{p}$ & Pore size(nm) & \multicolumn{4}{|c|}{$D_{p o}=0.00303 D_{m}( \pm 2.5)[36]$} \\
\hline & $D_{a}$ & Diameter of pit aperture $(\mu \mathrm{m})$ & \multicolumn{4}{|c|}{$D_{a}=0.25 D_{m}[24,36]$} \\
\hline & $D_{t}$ & Torus diameter $(\mu \mathrm{m})$ & \multicolumn{4}{|c|}{$0.50 D_{m}( \pm 0.11)[37-39]$} \\
\hline & $t_{a p}$ & Aperture thickness $(\mu \mathrm{m})$ & \multicolumn{4}{|c|}{ Equals $W_{t}$} \\
\hline & \multirow{2}{*}{$N_{p o}$} & \multirow{2}{*}{ Number of pores in pit membrane } & \multicolumn{4}{|c|}{ Formula (10) } \\
\hline & & & & & \multicolumn{2}{|c|}{$60-1050$} \\
\hline & $\alpha$ & Bordered pit density & \multicolumn{4}{|c|}{$6.5 \times 10^{8} \mathrm{~m}^{-2}[14,22,40]$} \\
\hline & $N_{\text {Bor }}$ & Number of bordered pit per tracheid & \multicolumn{4}{|c|}{ Formula (7) } \\
\hline \multirow{6}{*}{ 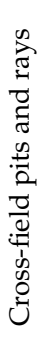 } & $W_{\text {ray }}$ & Height $(\mu \mathrm{m})$ & & & & \\
\hline & $t_{\text {ray }}$ & $\begin{array}{l}\text { Aperture thickness of cross-field pits } \\
\qquad(\mu \mathrm{m})\end{array}$ & \multicolumn{4}{|c|}{ The canal length of cross-field pit (ray thickness, approximately $W_{t}$ ) } \\
\hline & $D_{C r o}$ & The diameter of cross-field pits $(\mu \mathrm{m})$ & \multicolumn{2}{|c|}{$\begin{array}{l}\text { Formula (13) } \\
2.5-23.5\end{array}$} & \multicolumn{2}{|c|}{$\begin{array}{c}D_{\text {Cro }}=0.008 L_{t r}+1.564 \text { (Figure 8) } \\
1.55-1.8\end{array}$} \\
\hline & $\beta$ & The density of cross-field pits $\left(\mathrm{m}^{-2}\right)$ & \multicolumn{2}{|c|}{$1.96 \times 10^{8} \mathrm{~m}^{-2}$} & \multicolumn{2}{|c|}{$4.368 \times 10^{8} \mathrm{~m}^{-2}$} \\
\hline & \multirow{2}{*}{$N_{\text {Cro }}$} & \multirow{2}{*}{ Number of cross-field pits per tracheid } & \multicolumn{4}{|c|}{ Formula (8) } \\
\hline & & & \multicolumn{2}{|c|}{$2-15$} & \multicolumn{2}{|c|}{$3-30$} \\
\hline
\end{tabular}

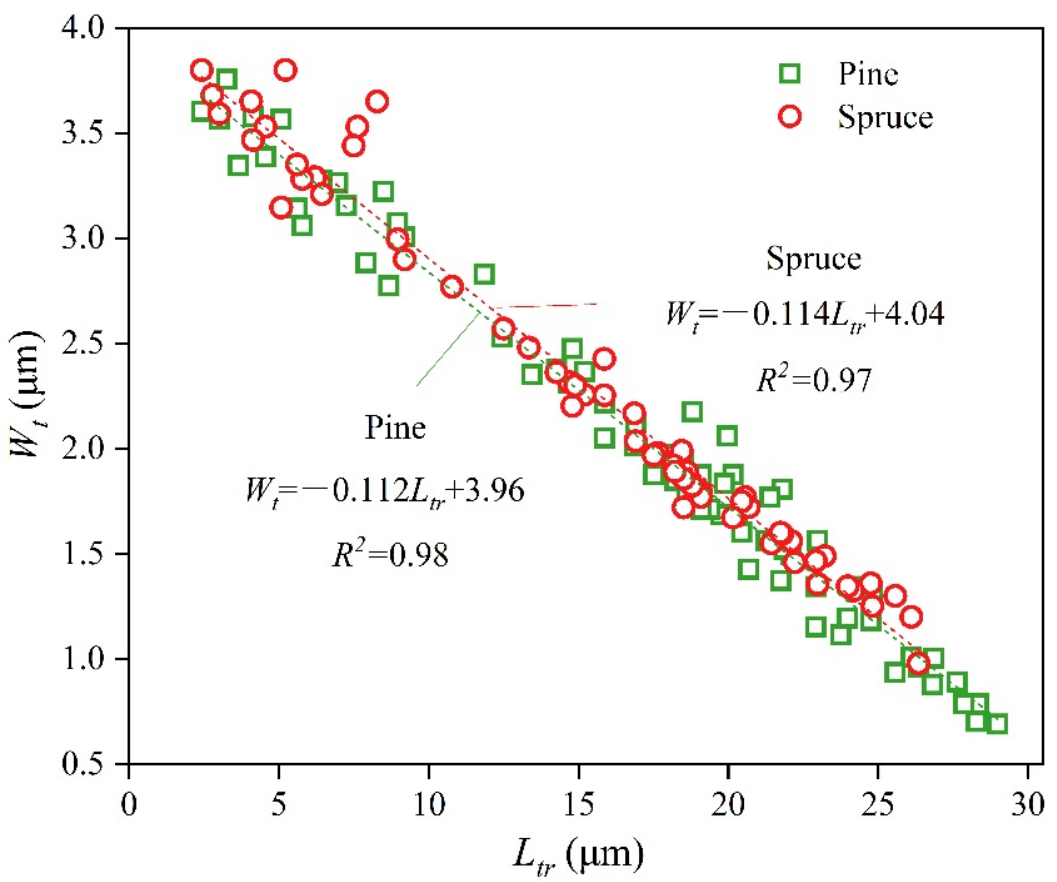

Figure 7. Wall thickness in relation to lumen radial diameter. $W_{t}$, a linear correlate of lumen radial diameter $L_{t r}$, tends to decrease with greater $L_{t r}$. Data points are mean wall thickness values corresponding to the lumen radial diameters of 68 pine tracheids (green box) and 61 spruce tracheids (red circle). 


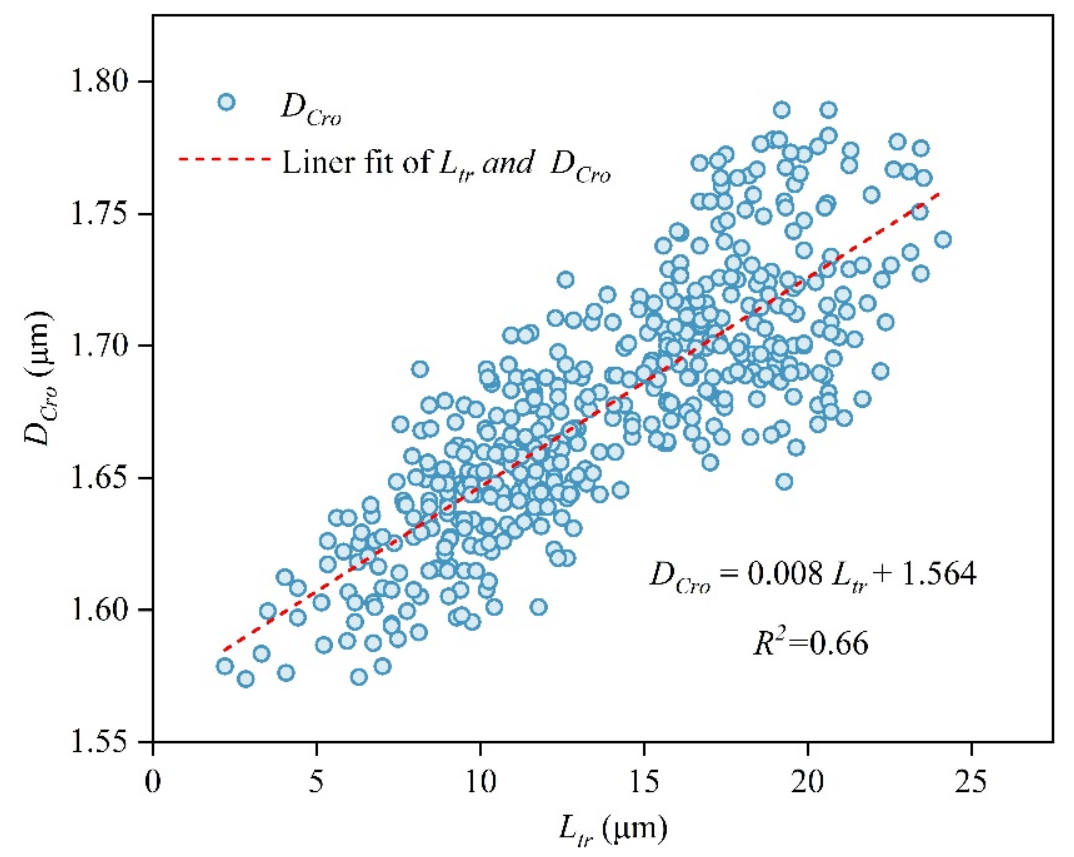

Figure 8. Scaling of cross-field pit diameter with lumen radial diameter $L_{t r}$ for spruce. The data points come from the measurement of the aperture size of 474 spruce cross-field pits (measurement method is shown in Figure 3c), $R^{2}=0.66$, slope 0.008 .

\subsection{Parameters Used in the Model and Range of Measured Values}

In this study, we calculated and evaluated the dimension parameters of each axial tracheid from earlywood and latewood, including the total number of bordered pits and cross-field pits on each axial tracheid, wood ray height, axial tracheid lumen diameter, and the density of two pits per unit image area, and so on. The numerical range of these parameters was measured and calculated, and the results are shown in Table 1.

Furthermore, due to the variability of morphological parameters including the size and number of anatomical structures in this work, we needed to integrate the isometric scaling between the radial diameter of tracheids $\left(L_{t r}\right)$ and all components of tracheid hydraulics. Through a large number of measurements, we found a relatively tight correlation between lumen radial diameter and the pit size of the pine and the spruce in this study, which was also proven by many previous studies. For example, in bordered pits, there was a certain linear relationship between the sizes of pit aperture and membrane, pit torus and pit membrane, and the regression slopes were 0.5 and 0.7 , respectively. These correlations of bordered pits match the approximate model parameters extracted from the literature $[24,29,36,37]$. In the two coniferous tree species we studied, the size of these components of bordered pits also had a similar size relationship, so our calculation method for this part was consistent with the literature (as shown in Table 1), which allowed us to model the bordered pits and other hydraulic components (lumens and walls) on the tracheids as a function of $L_{t r}$.

The challenge we faced was to increase the isometric relationship between the size and number of cross-field pits and $L_{t r}$ on the basis of the existing model, so as to realize the quantification of the hydraulic characteristics of the tracheid cell wall. Therefore, we measured the wall thickness $\left(W_{t}\right)$ and lumen radial diameter $\left(L_{t r}\right)$ of 68 pine tracheids and 61 spruce tracheids, and numerically analyzed the relationship between the $W_{t}$ and $L_{t r}$ of the two tree species according to the literature method $[24,29,36,37]$ mentioned above. It was found that there was a linear correlation between $W_{t}$ and $L_{t r}$ of the two tree species (Figure 7): pine: $W_{t}=-0.112 L_{t r}+4.04\left(R^{2}=0.97\right)$; spruce: $W_{t}=-0.114 L_{t r}+3.96\left(R^{2}=0.98\right)$. It can be seen that the wall thickness $W_{t}$ tended to decrease with greater $L_{t r}$, and there was little difference in the relationship between $W_{t}$ and $L_{t r}$ of these two conifers. This small 
difference was not taken into account in the subsequent calculation of the model. Therefore, the relationship was unified as $W_{t}=-80 / 7 \times L_{t r}+4$.

There was also a certain corresponding relationship between the size of the cross-field pits $\left(D_{C r o}\right)$ and the lumen radial diameter $\left(L_{t r}\right)$ of the two tree species. As the cross-field pits of the pine (Pinus sylvestris var. mongolica) were window-pane type and morphologically characteristic approximate rectangles, and thus easy to calculate, the corresponding relationship is shown in Formula (13). As for the spruce (Picea koraiensis Nakai), its cross-field pits were mainly piceoid type, and the morphology of the cross-field pits are shown in Figure 5g,h. We selected 474 spruce cross-field pits for measurement, and the SEM measurement tool was used to measure the radial dimension of the cross-field pit aperture $\left(D_{C r o}\right.$, measurement method is shown in Figure 3c). The corresponding relationship between the two was obtained by fitting, as shown in Figure 8 . Overall, the $D_{C r o}$ of the spruce term increased with greater $L_{t r}$ : slope 0.008 and $R^{2}=0.66$. Finally, the size of each hydraulic component of xylem was measured by a scanning electron microscope and a transmission electron microscope, and the number and isometric scaling relationship between tracheids and two kinds of pits and other parameters required for these models were counted, as shown in Table 1.

\subsection{Input Data and Model Output}

There were obvious differences in the proportions of earlywood and latewood in the two tree species collected in this study. Two groups of tracheids with similar ring widths (about $0.38 \mathrm{~mm}$ ) in transverse sections of the pine and spruce (as shown in Figures 5a and 6a) were selected to draw a schematic diagram reflecting the size and radial position of the tracheids, as shown in Figure 9. The tracheid wall thickness was calculated according to Table 1.

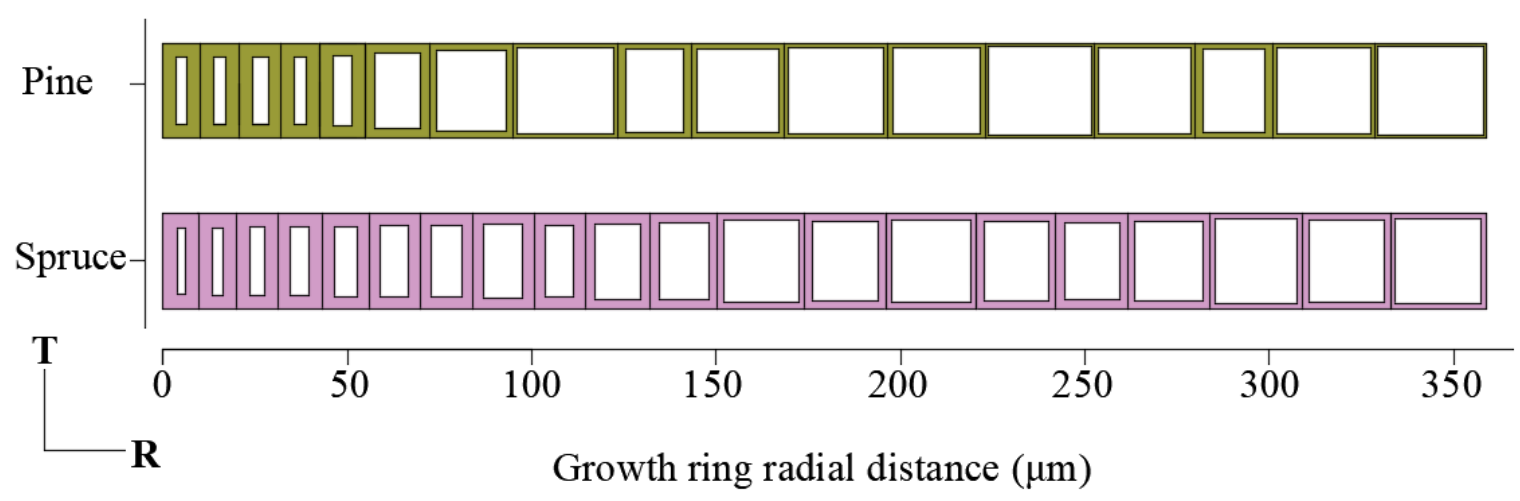

Figure 9. Tracheid diagram of two tree species with similar growth ring widths. The green box is the tracheid cross section of the pine (Pinus sylvestris L. var. mongholica Litv.), and the magenta box is the tracheid cross section of the spruce (Picea koraiensis Nakai).

The radial lumen diameters $\left(L_{t r}\right)$ were the input variables; EW stands for earlywood tracheid, LW, for latewood tracheid. For the output result: $R_{\text {wall }}$, sum of pit resistance; $R_{\text {lum }}$, lumen resistance; $R_{\text {tot }}$, tracheid resistance; $K$, tracheid conductance, and the structural parameters of tracheids and pits, such as $W_{t}, D_{m}, D_{a}$, and so on. To facilitate the comparison of the outputs of the two tree species model, the input parameters common to the two models were fixed as follows: tracheid length $H=2.7 \mathrm{~mm}$; tracheid tangential lumen diameter $T_{t r}=18 \mu \mathrm{m}$; mean thickness of margo strands $t_{f}=0.14 \mu \mathrm{m}$. We assumed that all ray parenchyma cells had the same height $W_{\text {ray }}=19 \mu \mathrm{m}$. The programming environment was used to formulate and run the model, and the operation results are shown in Table 2. 
Table 2. Hydraulic calculation of tracheidogram of two species in Figure 9.

\begin{tabular}{|c|c|c|c|c|c|c|c|c|c|c|c|c|c|c|}
\hline \multirow{2}{*}{\multicolumn{2}{|c|}{$\begin{array}{c}\text { Location } \\
\text { EW/ } \\
\text { LW }\end{array}$}} & \multicolumn{4}{|c|}{ Tracheid Characteristics } & \multicolumn{4}{|c|}{ Pit Characteristics } & \multicolumn{3}{|c|}{ Hydraulic Resistance } & \multicolumn{2}{|c|}{ Hydraulic Conductances } \\
\hline & & $\begin{array}{c}L_{t r} \\
(\mu \mathrm{m})\end{array}$ & $\begin{array}{c}W_{t} \\
(\mu \mathrm{m})\end{array}$ & $N_{b o r}$ & $N_{\text {cro }}$ & $\begin{array}{c}D_{m} \\
(\mu \mathrm{m})\end{array}$ & $\begin{array}{c}D_{a} \\
(\mu \mathrm{m})\end{array}$ & $\begin{array}{c}D_{t} \\
(\mu \mathrm{m})\end{array}$ & $\begin{array}{l}D_{C r o} \\
(\mu \mathrm{m})\end{array}$ & $\begin{array}{c}R_{\text {wall }} \\
\left(10^{14} \mathrm{~Pa} \mathrm{~s}\right. \\
\left.\mathrm{m}^{-3}\right)\end{array}$ & $\begin{array}{c}R_{\text {lum }} \\
\left(10^{14} \mathrm{~Pa} \mathrm{~s}\right. \\
\left.\mathrm{m}^{-3}\right)\end{array}$ & $\begin{array}{c}R \\
\left(10^{14} \mathrm{~Pa} \mathrm{~s}\right. \\
\left.\mathrm{m}^{-3}\right)\end{array}$ & $\begin{array}{c}\mathrm{K} \\
\left(10^{-15} \mathrm{~Pa}^{-1}\right. \\
\left.\mathrm{s}^{-1} \mathrm{~m}^{3}\right)\end{array}$ & $\begin{array}{c}K s c \\
\left(10^{-8} \mathbf{P a}^{-1}\right. \\
\left.\mathrm{s}^{-1} \mathrm{~m}^{2}\right)\end{array}$ \\
\hline \multicolumn{15}{|c|}{ Pine (Pinus sylvestris L. var. mongholica Litv.) } \\
\hline 1 & LW & 2.85 & 3.67 & 5 & 2 & 2.00 & 0.50 & 0.77 & 4.96 & 5559.79 & 939.93 & 6499.72 & 0.00 & 0.02 \\
\hline 2 & LW & 3.42 & 3.61 & 6 & 2 & 2.39 & 0.60 & 1.14 & 5.80 & 3328.35 & 504.92 & 3833.28 & 0.00 & 0.03 \\
\hline 3 & LW & 4.2 & 3.52 & 7 & 2 & 2.94 & 0.74 & 0.97 & 6.88 & 1838.52 & 256.13 & 2094.66 & 0.00 & 0.04 \\
\hline 4 & LW & 3.32 & 3.62 & 6 & 2 & 2.32 & 0.58 & 1.43 & 5.65 & 3620.46 & 558.02 & 4178.47 & 0.00 & 0.03 \\
\hline 5 & EW & 5.46 & 3.38 & 10 & 3 & 3.82 & 0.96 & 1.83 & 8.48 & 609.77 & 111.84 & 721.61 & 0.01 & 0.07 \\
\hline 6 & EW & 12.55 & 2.57 & 22 & 7 & 8.79 & 2.20 & 2.18 & 15.12 & 23.53 & 11.52 & 35.05 & 0.29 & 0.45 \\
\hline 7 & EW & 18.69 & 1.86 & 33 & 10 & 13.08 & 3.27 & 2.67 & 18.84 & 4.41 & 4.87 & 9.29 & 1.08 & 1.10 \\
\hline 8 & EW & 26.54 & 0.97 & 47 & 14 & 18.58 & 4.64 & 2.90 & 22.15 & 0.94 & 2.60 & 3.54 & 2.82 & 2.11 \\
\hline 9 & EW & 15.73 & 2.20 & 28 & 8 & 11.01 & 2.75 & 3.77 & 17.21 & 9.40 & 6.94 & 16.34 & 0.61 & 0.75 \\
\hline 10 & EW & 21.97 & 1.49 & 39 & 12 & 15.38 & 3.84 & 2.63 & 20.38 & 2.17 & 3.59 & 5.76 & 1.74 & 1.52 \\
\hline 11 & EW & 26.06 & 1.02 & 46 & 14 & 18.24 & 4.56 & 4.38 & 21.98 & 1.02 & 2.68 & 3.70 & 2.70 & 2.05 \\
\hline 12 & EW & 23.92 & 1.27 & 42 & 13 & 16.74 & 4.19 & 4.67 & 21.18 & 1.49 & 3.10 & 4.58 & 2.18 & 1.78 \\
\hline 13 & EW & 28.15 & 0.78 & 49 & 14 & 19.71 & 4.93 & 7.10 & 22.69 & 0.73 & 2.37 & 3.10 & 3.23 & 2.30 \\
\hline 14 & EW & 25.1 & 1.13 & 44 & 12 & 17.57 & 4.39 & 6.36 & 21.63 & 1.22 & 2.85 & 4.07 & 2.46 & 1.92 \\
\hline 15 & EW & 16.74 & 2.09 & 29 & 11 & 11.72 & 2.93 & 7.50 & 17.80 & 6.72 & 6.09 & 12.81 & 0.78 & 0.89 \\
\hline 16 & EW & 25.54 & 1.08 & 45 & 14 & 17.88 & 4.47 & 6.18 & 21.79 & 1.11 & 2.77 & 3.88 & 2.58 & 1.98 \\
\hline 17 & EW & 28.78 & 0.71 & 51 & 15 & 20.15 & 5.04 & 5.21 & 22.89 & 0.66 & 2.29 & 2.95 & 3.39 & 2.38 \\
\hline \multicolumn{15}{|c|}{ Spruce (Picea koraiensis Nakai) } \\
\hline 1 & LW & 2.20 & 3.75 & 4 & 3 & 1.54 & 0.39 & 0.77 & 1.58 & 4324.79 & 2332.20 & 6656.99 & 0.00 & 0.03 \\
\hline 2 & LW & 2.78 & 3.68 & 5 & 3 & 1.95 & 0.49 & 0.97 & 1.59 & 4150.08 & 1024.36 & 5174.44 & 0.00 & 0.03 \\
\hline 3 & LW & 4.08 & 3.53 & 7 & 5 & 2.86 & 0.71 & 1.43 & 1.60 & 2110.08 & 281.45 & 2391.53 & 0.00 & 0.03 \\
\hline 4 & LW & 5.22 & 3.40 & 9 & 6 & 3.65 & 0.91 & 1.83 & 1.61 & 1287.05 & 128.47 & 1415.52 & 0.01 & 0.04 \\
\hline 5 & LW & 6.22 & 3.29 & 11 & 7 & 4.35 & 1.09 & 2.18 & 1.61 & 764.71 & 75.44 & 840.15 & 0.01 & 0.05 \\
\hline 6 & LW & 7.62 & 3.13 & 13 & 9 & 5.33 & 1.33 & 2.67 & 1.62 & 351.42 & 41.93 & 393.35 & 0.03 & 0.08 \\
\hline 7 & LW & 8.28 & 3.05 & 15 & 10 & 5.80 & 1.45 & 2.90 & 1.63 & 247.35 & 33.30 & 280.65 & 0.04 & 0.10 \\
\hline 8 & EW & 10.78 & 2.77 & 19 & 13 & 7.55 & 1.89 & 3.77 & 1.65 & 75.51 & 16.67 & 92.18 & 0.11 & 0.21 \\
\hline 9 & EW & 7.50 & 3.14 & 13 & 9 & 5.25 & 1.31 & 2.63 & 1.62 & 373.02 & 43.85 & 416.87 & 0.02 & 0.07 \\
\hline 10 & EW & 12.5 & 2.57 & 22 & 15 & 8.75 & 2.19 & 4.38 & 1.66 & 37.56 & 11.63 & 49.19 & 0.20 & 0.32 \\
\hline 11 & EW & 13.34 & 2.48 & 23 & 16 & 9.34 & 2.33 & 4.67 & 1.67 & 27.54 & 10.00 & 37.54 & 0.27 & 0.39 \\
\hline 12 & EW & 20.28 & 1.68 & 36 & 24 & 14.20 & 3.55 & 7.10 & 1.73 & 3.71 & 4.17 & 7.88 & 1.27 & 1.20 \\
\hline 13 & EW & 18.18 & 1.92 & 32 & 21 & 12.73 & 3.18 & 6.36 & 1.71 & 6.26 & 5.15 & 11.40 & 0.88 & 0.92 \\
\hline 14 & EW & 21.44 & 1.55 & 38 & 25 & 15.01 & 3.75 & 7.50 & 1.74 & 2.85 & 3.76 & 6.61 & 1.51 & 1.36 \\
\hline 15 & EW & 17.65 & 1.98 & 31 & 21 & 12.36 & 3.09 & 6.18 & 1.71 & 7.20 & 5.46 & 12.67 & 0.79 & 0.85 \\
\hline 16 & EW & 14.89 & 2.30 & 26 & 18 & 10.42 & 2.61 & 5.21 & 1.68 & 16.27 & 7.81 & 24.08 & 0.42 & 0.54 \\
\hline 17 & EW & 18.44 & 1.89 & 32 & 22 & 12.91 & 3.23 & 6.45 & 1.71 & 5.84 & 5.00 & 10.85 & 0.92 & 0.95 \\
\hline 18 & EW & 22.22 & 1.46 & 39 & 26 & 15.55 & 3.89 & 7.78 & 1.74 & 2.41 & 3.52 & 5.93 & 1.69 & 1.47 \\
\hline 19 & EW & 20.56 & 1.65 & 36 & 24 & 14.39 & 3.60 & 7.20 & 1.73 & 3.48 & 4.06 & 7.54 & 1.33 & 1.24 \\
\hline 20 & EW & 23.22 & 1.35 & 41 & 27 & 16.25 & 4.06 & 8.13 & 1.75 & 1.95 & 3.26 & 5.21 & 1.92 & 1.60 \\
\hline
\end{tabular}

Measurements were made of the approximate widths of growth rings for the pine (Pinus sylvestris L. var. mongholica Litv.) and the spruce (Picea koraiensis Nakai). $L_{t r}$ of each tracheid in the growth ring is the input variable; EW, earlywood tracheid; LW, latewood tracheid; Output result: $R_{\text {wall }}$, sum of pit resistance; $R_{\text {lum }}$, lumen resistance; $R_{\text {tot }}$, tracheid resistance; $K$, tracheid conductance. To facilitate the comparison of the outputs of the two tree species model, the input parameters common to the two models were fixed as follows: tracheid length $H=2.7 \mathrm{~mm}$; tracheid tangential lumen diameter $T_{t r}=18 \mu \mathrm{m}$; mean thickness of margo strands $t_{f}=0.14 \mu \mathrm{m}$. We assumed that all ray parenchyma cells had the same height $W_{\text {ray }}=19 \mu \mathrm{m}$.

Although the growth ring widths of the two tree species we selected were similar $(358.9 \mu \mathrm{m})$, they were composed of differently sized tracheids (see Figure 9 for tracheid schematic diagram). The variation range of tracheid conduction in the growth rings of 
the two tree species was calculated to be three orders of magnitude. The contribution of latewood tracheids to the conductivity of both rings of the two species was less than $1 \%$. The minimum value was less than 0.01 , and the maximum value was 4.24 for the pine and 1.92 for the spruce (Unit, $10^{-15} \mathrm{~Pa}^{-1} \mathrm{~s}^{-1} \mathrm{~m}^{3}$ ). The growth ring conduction value of the pine $\left(23.88 \times 10^{-15} \mathrm{~Pa}^{-1} \mathrm{~s}^{-1} \mathrm{~m}^{3}\right)$ was more than twice that of the spruce $\left(11.42 \times 10^{-15} \mathrm{~Pa}^{-1} \mathrm{~s}^{-1} \mathrm{~m}^{3}\right)$. In the growth rings, except for a few latewood tracheids, the overall flow resistance of pine was mostly less than that of the spruce, that is, the conductivity was found to be better for the pine than the spruce. Through statistical analysis, this change was mainly caused by the difference of tracheid structure and the characteristics of cross-field pits. The cross section of the earlywood tracheids from the pine had a larger radial dimension than that of the spruce, and the proportion of earlywood tracheids in the pine was significantly larger than that in latewood. In addition, there is a large difference in the size of pits in the cross field of the two tree species (several times or even dozens of times).

\subsection{Application of the New Tissue Model to the Pine and the Spruce}

When quantitatively calculating the hydraulic characteristics of tracheids with different sizes, and especially when considering the interannual variation in wood anatomical structure, the different sizes of tracheids and the characteristics of bordered pits and crossfield pits will have a significant impact on the hydraulic resistance. In order to further verify that the characteristics of cross-field pits are an important factor affecting xylem flow resistance and conductivity, we set the tracheid size and corresponding bordered pits density of the two tree species to be consistent, and the isometric relationship applied in the model is shown in Table 1. Here, the variables were only the size and number of cross-field pits, which were obtained by measuring samples selected in this paper, as shown in Table 2 and Figure 10.

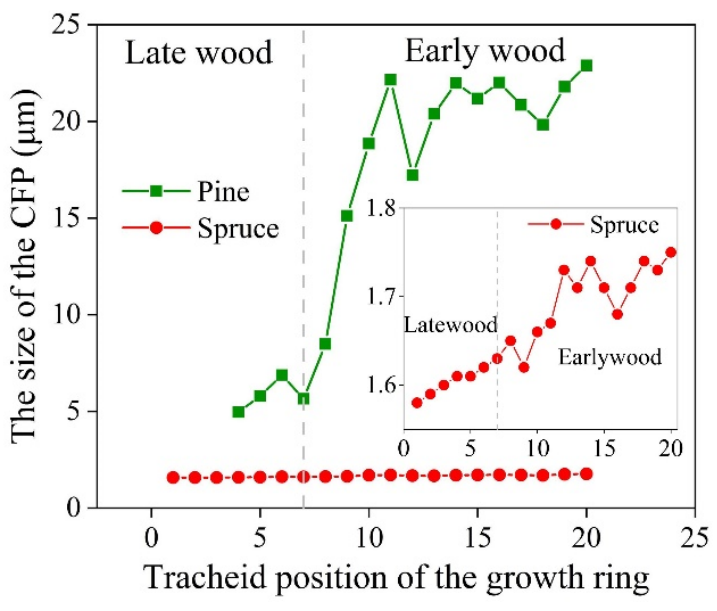

(a)

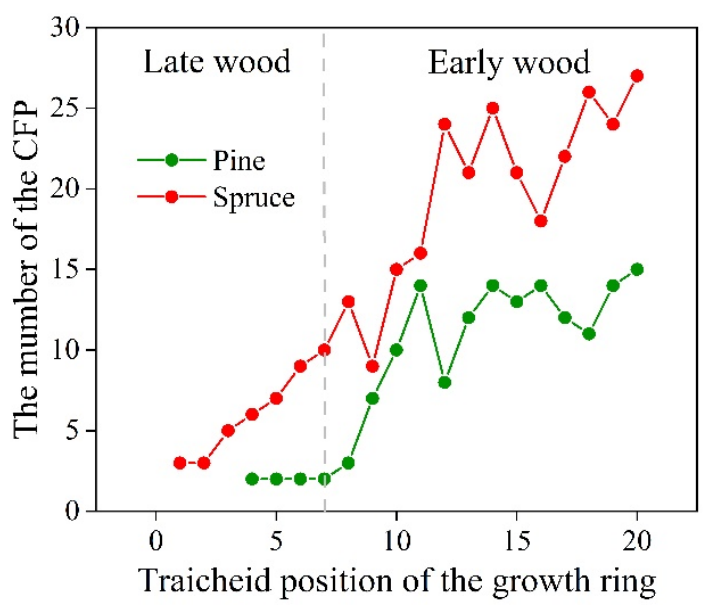

(b)

Figure 10. Statistical results of cross-field pits on each tracheid of the pine (Pinus sylvestris L. var. mongholica Litv.) and spruce (Picea koraiensis Nakai) with an approximate growth-ring width obtained by SEM. (a) Comparison of the pit sizes of the cross fields of the two tree species in one growth ring (refer to Figure 3 and Formula (11) for the measurement and calculation method). (b) The number of cross-field pits of the two species in one growth ring.

Figure 10a shows that there was a large difference in the cross-field pit size between the earlywood and latewood of the pine and the spruce. The cross-field pit size of the earlywood of the pine was several times to dozens of times that of the latewood, while the cross-field pit size of earlywood of the spruce was relatively stable, with the difference in fluctuation being relatively small. Figure $10 \mathrm{~b}$ shows that the number of cross-field pits on each tracheid was lower for the pine than for the spruce. This is because the number 
of cross-field pits of each cross field of the pine was usually one and that of the spruce was usually two to seven. According to the characteristic parameters of cross-field pits in Figure 10 we brought them into the model for targeted analysis to determine the influence of the number and size of cross-field pits on the wall resistance of the two tree species, as shown in Figure 11.

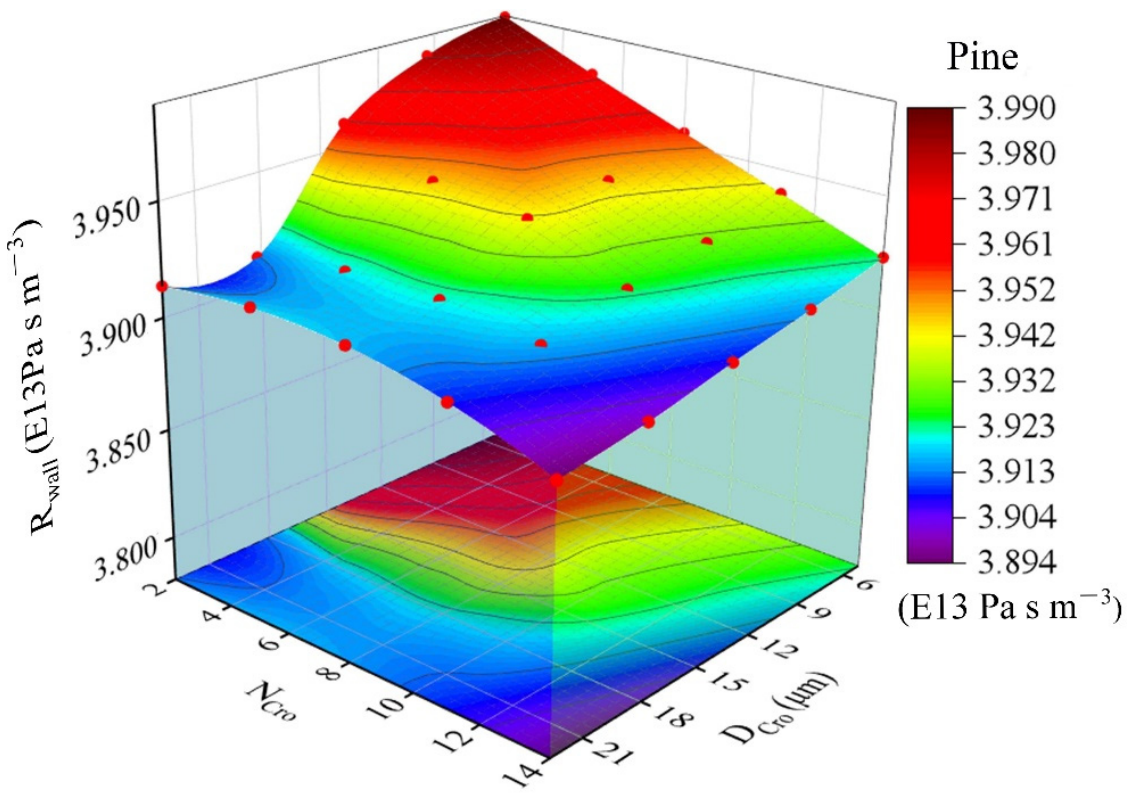

(a)

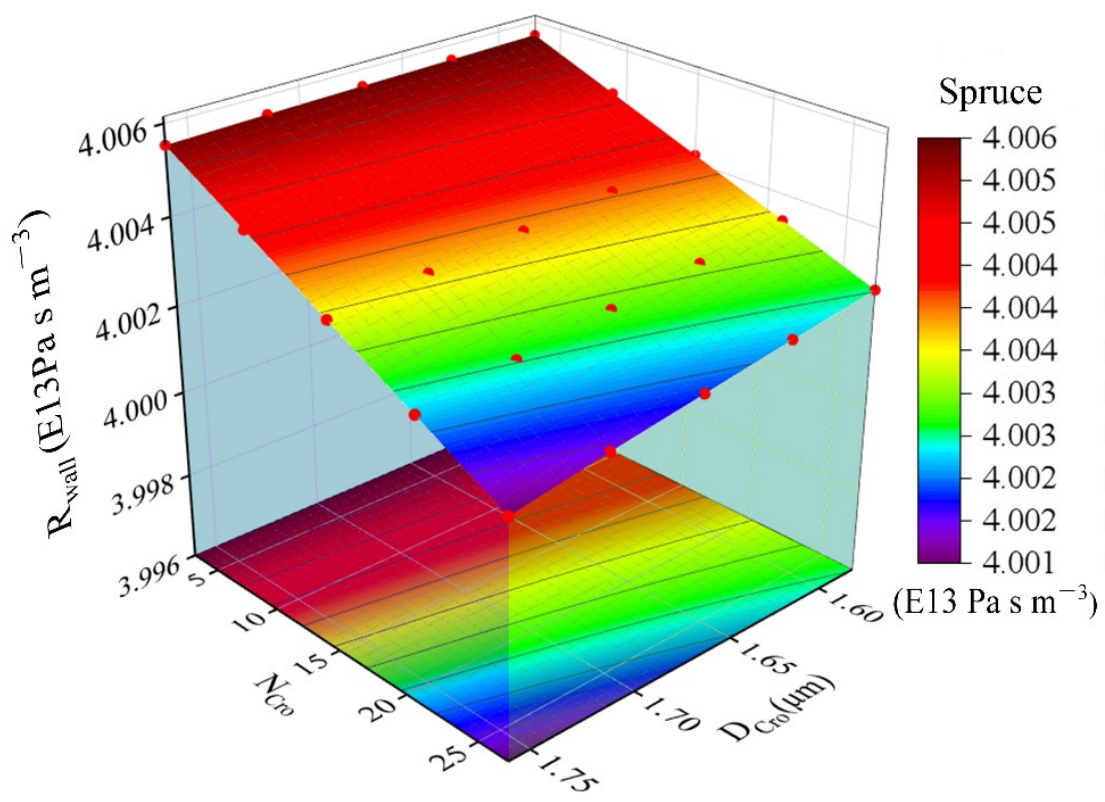

(b)

Figure 11. Relationship between the number and size of cross-field pits and wall resistance of two tree species. (a) The pine (Pinus sylvestris L. var. mongholica Litv.); (b) the spruce (Picea koraiensis Nakai).

When the characteristics of tracheids and bordered pits are the same, and the variables are only the number and size of cross-field pits, it can be seen from Figure 11 that, generally, as the size and number of cross-field pits increase, both the pine and the spruce show a downward trend in wall resistance. However, the variation range of wall resistance of the pine is much larger than that of the spruce (the pine is $9.6 \times 10^{11} \mathrm{~Pa} \mathrm{~s} \mathrm{~m}^{-3}$ and the spruce is $0.5 \times 10^{11} \mathrm{~Pa} \mathrm{~s} \mathrm{~m}^{-3}$ ). While the wall resistance of the pine reflects the result of 
the interaction of the two factors, it can be seen from Figure 11a that the wall resistance of the pine changed significantly with the cross-field pit size increase; it can be seen from Figure $11 \mathrm{~b}$ that the wall resistance surface of the spruce is relatively stable. In contrast, the slope of wall resistance with the change of number was larger than that of size, indicating that the number had a more significant impact on wall resistance. Through analysis, the difference between them was consistent with the law of the differences in the structural characteristics of the two tree species in Figure 10. By observing a large number of samples, the number of cross-field pits in both species was at the same order of magnitude, and the difference was less than twice, but the size of cross-field pits of the pine was large and the variation range was several times to dozens of times, while the size of cross-field pits of the spruce was small, the variation range was also small, and the difference was generally less than $20 \%$. According to the mathematical relationship in the above model, the resistance of the pine was sensitive to the size change of cross-field pits, while the size change of cross-field pits had little effect on the resistance of the spruce.

In addition, we calculated their conductivity, as shown in Figure 12a. When considering roughly the same ring width, most of the wall conductivity of the two tree species mainly depended on the earlywood tracheids, and the wall conductivity of the pine was greater than that of the spruce. On this basis, the number of samples was expanded to calculate the sum of the total conductivity of each growth ring and to analyze the conductivity difference between the two species (calculate according to Formula (17)). The obtained statistical results are shown in Figure 12b, with the two star points corresponding to the conduction values of the two tree species in Figure 9. On the whole, the conductivity of the pine was higher than that of the spruce. This also explains the previous conclusion that the conductivity and permeability of the spruce were relatively weak from the perspective of theoretical calculation.

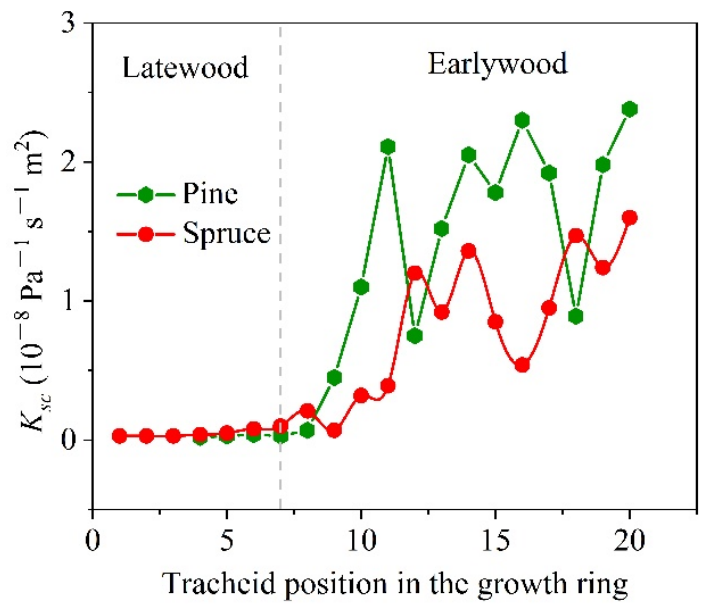

(a)

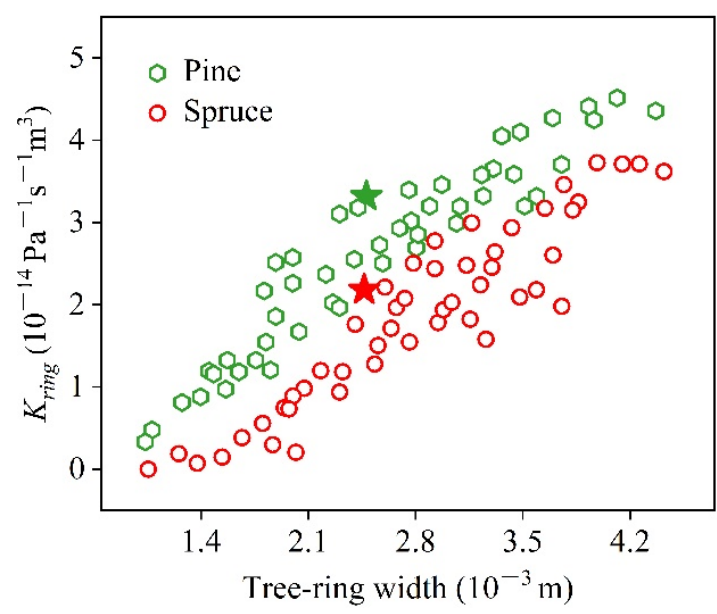

(b)

Figure 12. The influence of the cross-field pit size and number of the two tree species on hydraulic conductance. (a) Each point represents the specific conductivity value $\left(K_{s c}\right)$ corresponding to one tracheid in Figure 9. (b) Each point represents the accumulation of a set of complete tracheid conduction values in the ring, namely $K_{\text {ring, }}$ and two star points represent the ring conduction values from the two tree species in Figure 9. 


\subsection{Validation}

Although many studies have successively proved the important role of cross-field pits in hydraulic conductivity, there is no relevant report on incorporating the conduction role of cross-field pits into the model calculation. Therefore, there is no completely consistent empirical method to evaluate the accuracy of our newly constructed tissue model in describing and calculating the hydraulic characteristics of coniferous xylem. However, in previous studies, there are many related introductions about the calculation of flow resistance and specific conductivity $\left(K_{s c}\right)$ of each tracheid. Therefore, we adopted the method of cross-validation with the existing literature and used the model proposed in this study to calculate the flow resistance and the conductivity $[18,19,22,38]$.

The spruce, one of the research objects, belongs to the same tree species as those in the literature $[18,20,22,37,38]$, and the types of cross-field pits are consistent. We compared the calculated resistance of each component on the tracheid with that of previous studies [19], and cross-verified the flow resistance contribution of each component of a single bordered pit with the model calculation results of Schulte et al. [38]. The two figures show the absolute values on a logarithmic scale $(\log 10)$. As expected, the resistance of pits and tracheids decreases exponentially with the increase in radial lumen diameter $L_{t r}$, and the two figures show the absolute values on a logarithmic scale $(\log 10)$. When the values of $L_{t r}$ $(14.3-18.6 \mu \mathrm{m})$ close to the literature are input, our calculation results are within the resistance range of the hydraulic components of bordered pits $\left(6 \times 10^{15}-1.3 \times 10^{16} \mathrm{~Pa} \mathrm{~s} \mathrm{~m}^{-3}\right)$ in the literature (as shown by the red rectangle in Figure 13a), and only part of the resistance value from margo is slightly out of range. The bordered pit resistance calculated by this model was in an approximate order of magnitude with the results calculated in the literature. When the values of $L_{t r}(10-22 \mu \mathrm{m})$ close to the literature were input, the lumen resistance $\left(R_{\text {lum }}\right)$ and total resistance of tracheid $\left(R_{t o t}\right)$ were within a reasonable range and overlapped well with the resistance value range of the hydraulic components of tracheid $\left(2.6 \times 10^{14}-3.5 \times 10^{16} \mathrm{~Pa} \mathrm{~s} \mathrm{~m}^{-3}\right)$ in the literature (as shown in the magenta rectangle in Figure 13b). These comparison results prove the effectiveness of the model proposed in this study to a certain extent.

For further verification, we used the model of this study to calculate the specific conductivity per tracheid $\left(K_{s c}\right)$ with and without cross-field pits, and compared with the value of the specific conductance per tracheid $\left(K_{s c}\right)$ obtained by the traditional method [16]. According to the calculation method proposed in this study, the $K_{s c}$ value of tracheids considering cross-field pits and bordered pits was slightly greater than that considering only tracheids and bordered pits (as shown by the blue line and green line in Figure 13c. The main reason why the difference was so small was that the number of cross-field pits was small. The calculation method is as shown in Formula (6)). At the same time, the specific conductivity $K_{s c}$ of tracheids calculated by this research model was compared with the results calculated by the traditional model (red dot in Figure 13c). In general, they had an upward trend with the increase in the hydraulic diameter of the tracheid, and the difference between the two methods was within a reasonable range, which further proves the effectiveness of this research model. 


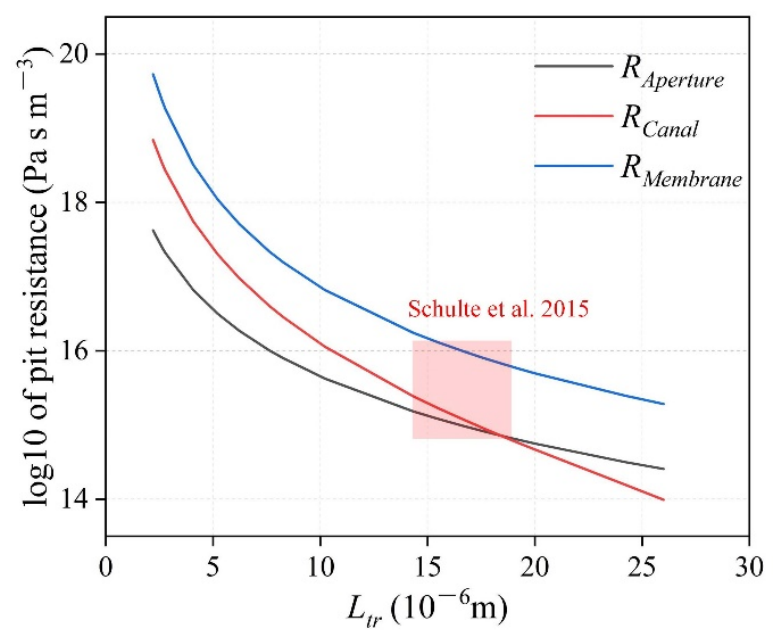

(a)

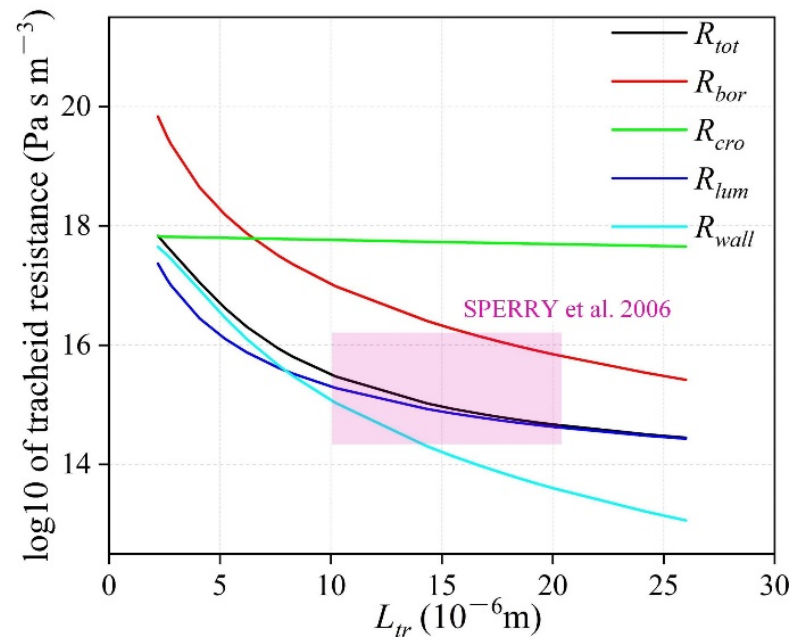

(b)

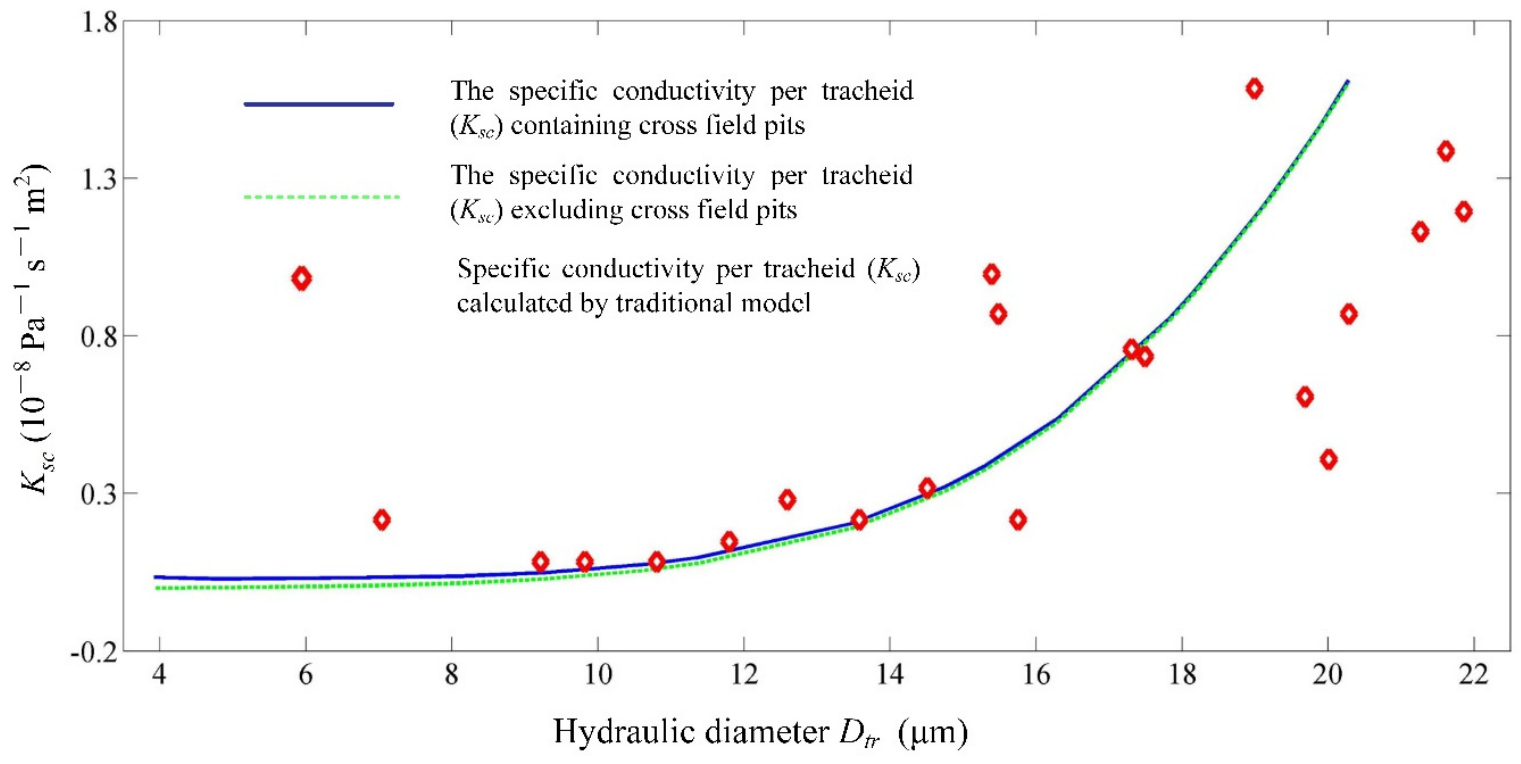

(c)

Figure 13. Comparing the model results with those of the literature review. (a) With the change of tracheid size, the resistance value of each component of bordered pits; (b) the resistance of each part of the tracheid as the size of the tracheid changes. The two figures show the absolute values on a logarithmic scale $(\log 10)$, and the boxed area in them represent the part where the resistance value range of tracheids and pits in the literature is similar to the range of our simulation results when the approximate $L_{t r}$ is input $[16,22,38]$. (c) The specific conductivity per tracheid $\left(K_{s c}\right)$ with and without cross-field pits calculated by the model of this study, and compared with the value of the specific conductance per tracheid $\left(K_{s c}\right)$ obtained by the traditional method [16].

\section{Discussion}

The hydraulic conduction model proposed in this paper is an improvement of the model from previous studies that simply considers a single tracheid or a group of independent tracheids [18-20,22], and extends it to the tissue scale. Through the above verification of the model proposed in this study (Figure 13a), we can see that the resistance calculation value of cross-field pits is large, but its number is less than that of the bordered pits (Table 1). Therefore, through the model calculation, it has relatively little impact on the overall conductance of the cell wall, so that the magnitude of the final total flow resistance of tracheid is consistent with the research results of the previous literature $[18,19,22,38]$. It 
should be added that although the conduction effect of the cross-field pits occupied less influence in a single tracheid (Figure 13c), the significance of this study is that it can be applied to a more precise and comprehensive analysis of the influence of the structure of each part of the xylem on the hydraulic flow in the future. The resistance values caused by margo were slightly out of range (Figure 13b); the reason for the difference was that the margo pore size of coniferous wood was actually different in physiology. However, for the convenience of calculation, the margo pore was set as the equivalent pore $D_{p o}$ of the same size according to the method of the literature in the model [18], which may have increased the resistance caused by margo to a certain extent [13-17]. In addition, an important finding was that the transition of resistance from pit-dominated to lumen-dominated occurred around the transition between earlywood and latewood. This means that the water transfer capacity of the earlywood is not mainly limited by pits (Figure 13a). In other words, as the size of tracheids increases, the resistance caused by the pits decreases faster than the lumen resistance. In addition, the tracheids of latewood have a particularly small contribution to the water conduction in the interannual cycle (Table 2), on the one hand because of their narrow lumen, and on the other hand, because there are few pits that connect the tracheids. Therefore, regarding our samples, it is not surprising that the latewood tracheids of the two tree species contribute less than $1 \%$ to the growth ring conductance.

In addition, we know that wood rays occupy about $7-20 \%$ of the xylem volume of conifer, and the cross-field pits on them play an important role in the water flow between axial tracheids and ray parenchyma cells. The model proposed in this paper exploratively incorporated the conduction of the cross-field pits into the calculation of the xylem hydraulic conduction model. However, it needs to be noted that when considering the conduction of wood rays, this article mainly considered the effects of the type and number of cross-field pits (combined with the size and ratio of rays) on the conduction of adjacent axial tracheids, ignoring the calculation of the radial conduction resistance of wood rays. This is because the theory that cross-field pits can facilitate water conduction is almost certain. Many physiological studies have evaluated the importance of cross-field pits as the conductors of liquid between axial tracheids and wood rays, and also proven that the flow resistance caused by cross-field pit ultrastructure cannot be ignored [6-8,14]. However, many scholars hold different opinions on whole tree hydraulics and, in particular, whether wood rays can radially conduct and the factors that can regulate radial flow $[2,3,11,41,42]$. Nevertheless, literature searches reveal a paucity of investigations into the influence of wood ray internal filling materials on hydraulic function. Therefore, the evaluation of the hydraulic conductivity of wood rays requires more in-depth research, so as to improve the dynamic understanding of the radial conduction of wood rays and have a clearer understanding of the hydraulic conduction pathways. In this way, the impact of wood rays on the hydraulic characteristics of a single tracheid, a group of growth rings and the entire xylem can be evaluated more comprehensively and quickly through the model, and the gap in understanding how the water movement in the wood rays affects the hydraulic function of the entire wood can be made up.

In the future, we need to evaluate the effectiveness of our model output through experimental verification, for example, by using advanced tools, for example, the xyl'em device (INRA France) and the Cavitron [22,43], or the visual analysis of the conduction path, and the measurement and calculation of conduction resistance by injecting tracer liquid into living trees $[1,3,26]$. These hydraulic measurements can be more systematically combined with xylem anatomical structure, and can be applied to comprehensively consider the hydraulic conduction of tracheids, bordered pits and cross-field pits. Furthermore, differences in the physiological characteristics of different tree species and in the growth environment will affect the wood tissue structure, such as in determining whether, ultrastructurally, the cross-field pit membranes of different tree species have radially arranged microfibrils, whether the two sides of the pit membrane are often covered or embedded with microfibrils, etc. [6,7]. The extent of the influence of these problems on hydraulic conduction resistance requires in-depth exploration and research. 
More in-depth research is needed to evaluate the hydraulic conductivity of wood rays, so as to improve the dynamic understanding of radial conduction of wood rays and better understand the hydraulic conduction pathway. Thus, the model can more comprehensively and quickly evaluate the impact of wood rays on the hydraulic characteristics of a single tracheid, a group of growth rings and the whole xylem, so as to make up the understanding gap of how the water movement of wood rays affects the hydraulic function of the whole wood. In addition, we plan to further target in-situ anatomical measurements, including coniferous samples from different seasons, different tree species, different heights (including stems and roots) and different positions (shady and sunny sides) [37], which can provide a solid data basis for cross validation for our model study of xylem microstructure and hydraulic characteristics. This will allow us to analyze the significant factors affecting xylem conduction in a larger sample capacity, so as to refine the model analyzing the relationship between pit structure and hydraulic characteristics such that it is more accurate. At the same time, it can be extended to other tree species in the future to evaluate the relationship between the morphological characteristics and flow characteristics of wood rays and crossfield pits of different tree species, so as to provide a reference basis for wood seed selection, wood processing, and utilization.

\section{Conclusions}

Previous research models on the relationship between the xylem structure and hydraulic conduction of conifer have mainly focused on tracheids and bordered pits, but the conduction model of the cross-field pits that connect tracheids and ray parenchyma cells have rarely been studied. In this study, we constructed a more comprehensive model that extends to the tissue scale, and our model is convenient for assessing the relationship between xylem structure and hydraulic properties because it only requires a more easily available measurement of cross-sectional tracheid size. The micro morphology and structural parameters of xylem of two tree species were collected by scanning electron microscope and transmission electron microscope. The improved model can quantify the important hydraulic functional characteristics of xylem only by measuring the more easily obtained cross-sectional tracheid size. The model can quantitatively analyze the comprehensive effects of the structural size of tracheids and bordered pits, as well as the type, number and size of cross-field pits on the hydraulic properties. In terms of model application, we selected two coniferous species with distinctive characteristics and a wide global distribution as the research object for analysis and verification. It was concluded that for these two species, the wall resistance of the pine reflects the result of the interaction of the size and number of cross-field pits, and changes significantly with the size of cross-field pits. In comparison, the wall resistance of the spruce was more sensitive to the number of cross-field pits. The transition of resistance from pit-dominated to lumen-dominated occurred around the transition between earlywood and latewood, and the growth ring conduction value of the pine $\left(23.88 \times 10^{-15} \mathrm{~Pa}^{-1} \mathrm{~s}^{-1} \mathrm{~m}^{3}\right)$ was more than twice that of the spruce $\left(11.42 \times 10^{-15} \mathrm{~Pa}^{-1} \mathrm{~s}^{-1} \mathrm{~m}^{3}\right)$ for the two tree species with similar growth ring widths in this study. Finally, the validity and accuracy of the model were evaluated by cross-validation with the results of previous research, and the reasons for the small differences were analyzed. The model presented here can provide references for the analysis of the influence of xylem structure and hydraulic characteristics and the study of tree cultivation. At the same time, it provides additional insights for the study of wood permeability, processing, and utilization. The proposed model not only contributes to the study of tree physiology, but also provides a more comprehensive and effective method for wood species selection, cultivation, and the functional improvement of wood. 


\begin{abstract}
Author Contributions: Conceptualization, W.Q.; data curation, W.Q.; investigation, J.Z. and X.T.; methodology, Y.M.; software, W.Q.; writing-original draft, W.Q. and C.Y.; writing-review and editing, W.Y. validation, S.Z. All authors have read and agreed to the published version of the manuscript.

Funding: This research was funded by "Major special research and development projects in Guangdong Province (2020B020216001)", "Natural Science Foundation of Heilongjiang Province (ZD2021E001)” and "Fundamental Research Funds for the Central Universities (2572019CP18)".
\end{abstract}

Institutional Review Board Statement: Not applicable.

Informed Consent Statement: Not applicable.

Data Availability Statement: Not applicable.

Acknowledgments: The authors of this paper would like to thank Tao Zhang for fruitful discussion on xylem anatomy, technical aspects of the measurements and useful suggestions.

Conflicts of Interest: The authors declare no conflict of interest.

\title{
References
}

1. Williams, C.B.; Anfodillo, T.; Crivellaro, A.; Lazzarin, M.; Dawson, T.E.; Koch, G.W. Axial variation of xylem conduits in the Earth's tallest trees. Trees-Struct. Funct. 2019, 33, 1299-1311. [CrossRef]

2. Kim, J.S.; Awano, T.; Yoshinaga, A.; Takabe, K. Temporal and spatial diversities of the immunolabeling of mannan and xylan polysaccharides in differentiating earlywood ray cells and pits of Cryptomeria japonica. Planta 2011, 233, 109-122. [CrossRef]

3. Barnard, D.M.; Lachenbruch, B.; Mcculloh, K.A.; Kitin, P.; Meinzer, F.C. Do ray cells provide a pathway for radial water movement in the stems of conifer trees? Am. J. Bot. 2013, 100, 322-331. [CrossRef]

4. Fang, W.; Wu, Y. Tissue Ratio of Conifer Wood. J. Northeast For. Univ. 2007, 35, 12-14.

5. Hajek, P.; Kurjak, D.; von Wühlisch, G.; Delzon, S.; Schuldt, B. Intraspecific variation in wood anatomical, hydraulic, and foliar traits in ten European beech provenances differing in growth yield. Front. Plant Sci. 2016, 7, 791. [CrossRef]

6. Zimmer, K.; Treu, A.; McCulloh, K.A. Anatomical differences in the structural elements of fluid passage of Scots pine sapwood with contrasting treatability. Wood Sci. Technol. 2014, 48, 435-447. [CrossRef]

7. Usta, I.; Hale, M.D. Radial permeability of sitka spruce as affected by wood structure-Permeability of cross-field pits in uniseriate rays. IAWA J. Int. Assoc. Wood Anat. 2003, 24, 197-204. [CrossRef]

8. Tarmian, A.; Azadfallah, M.; Gholamiyan, H.; Shahverdi, M. Inter-Tracheid and Cross-Field Pitting in Compression Wood and Opposite Wood of Norway Spruce (Picea abies L.). Notulae Sci. Biol. 2011, 3, 145-151. [CrossRef]

9. Morris, H.; Plavcova, L.; Cvecko, P.; Fichtler, E.; Gillingham, M.A.F.; Martínez-Cabrera, H.I.; McGlinn, D.J.; Wheeler, E.; Zheng, J.; Zieminska, K.; et al. A global analysis of parenchyma tissue fractions in secondary xylem of seed plants. New Phytol. 2016, 209, 1553-1565. [CrossRef]

10. Siau, J.F. Wood: Influence of Moisture on Physical Properties; Department of Wood Science and Forest Products, Virginia Polytechnic Institute: State University, VA, USA, 1995.

11. Zhao, Y.; Bao, F. Theoretical analysis on the relationship between fluid longitudinal permeability and structure of conifer wood. For. Sci. 1998, 34, 90-97.

12. Martínez-Vilalta, J.; Mencuccini, M.; Álvarez, X.; Camacho, J.; Loepfe, L.; Piñol, J. Spatial distribution and packing of xylem conduits. Am. J. Bot. 2012, 99, 1189-1196. [CrossRef]

13. Pittermann, J.; Limm, E.; Rico, C.; Christman, M.A. Structure-function constraints of tracheid based xylem. A comparison of conifers and ferns. New Phytol. 2011, 192, 449-461. [CrossRef]

14. Sperry, J.S.; Hacke, U.G. Analysis of circular bordered pit function I. Angiosperm vessels with homogenous pit membranes. Am. J. Bot. 2004, 91, 369-385. [CrossRef]

15. Lancashire, J.R.; Ennos, A.R. Modelling the hydrodynamic resistance of bordered pits. J. Exp. Bot. 2002, 373, 1485-1493. [CrossRef]

16. Hacke, U.G.; Sperry, J.S.; Pittermann, J. Analysis of circular bordered pit function. II. Gymnosperm tracheids with torus-margo pit membranes. Am. J. Bot. 2004, 91, 386-400. [CrossRef]

17. Hacke, U.G.; Sperry, J.S.; Wheeler, J.K.; Castro, L. Scaling of angiosperm xylem structure with safety and efficiency. Tree Physiol. 2006, 26, 689-701. [CrossRef]

18. Wilson, J.P.; Knoll, A.H.; Holbrook, N.M.; Marshall, C.R. Modeling fluid flow in Medullosa, an anatomically unusual Carboniferous seed plant. Paleobiology 2008, 34, 472-493. [CrossRef]

19. Sperry, J.S.; Hacke, U.G.; Pittermann, J. Size and function in conifer tracheids and angiosperm vessels. Am. J. Bot. 2006, 93, 1490-1500. [CrossRef]

20. Tanrattana, M.; Barczi, J.F.; Decombeix, A.L.; Meyer-Berthaud, B.; Wilson, J. A new approach for modelling water transport in fossil plants. IAWA J. 2019, 40, 466-487. [CrossRef]

21. Venturas, M.D.; Sperry, J.S.; Hacke, U.G. Plant xylem hydraulics: What we understand, current research, and future challenges. J. Integr. Plant Biol. 2017, 59, 356-389. [CrossRef] 
22. Sviderskaya, I.V.; Vaganov, E.A.; Fonti, M.V.; Fonti, P. Isometric scaling to model water transport in conifer tree rings across time and environments. J. Exp. Bot. 2021, 6, 2672-2685. [CrossRef]

23. Lazzarin, M.; Crivellaro, A.; Williams, C.B.; Dawson, T.E.; Mozzi, G.; Anfodillo, T. Tracheid and pit anatomy vary in tandem in a tall sequoiadendron giganteum tree. IAWA J. 2016, 37, 172-185. [CrossRef]

24. Pittermann, J.; Choat, B.; Jansen, S.; Stuart, S.A.; Lynn, L.; Dawson, T.E. The relationships between xylem safety and hydraulic efficiency in the Cupressaceae: The evolution of pit membrane form and function. Plant Physiol. 2010, 153, 1919-1931. [CrossRef]

25. Blokhina, O.; Laitinen, T.; Hatakeyama, Y.; Delhomme, N.; Paasela, T.; Zhao, L.; Street, N.R.; Wada, H.; Kärkönen, A.; Fagerstedt, K. Ray parenchymal cells contribute to lignification of tracheids in developing xylem of Norway spruce. Plant Physiol. 2019, 181, 1552-1572. [CrossRef]

26. Kitin, P.; Fujii, T.; Abe, H.; Takata, K. Anatomical features that facilitate radial flow across growth rings and from xylem to cambium in Cryptomeria japonica. Ann. Bot. 2009, 103, 1145-1157. [CrossRef]

27. Pfautsch, S.; Hölttä, T.; Mencuccini, M. Hydraulic functioning of tree stems-Fusing ray anatomy, radial transfer and capacitance Tree Physiol. 2015, 35, 706-722. [CrossRef]

28. Bonetti, S.; Breitenstein, D.; Fatichi, S.; Domec, J.; Or, D. Persistent decay of fresh xylem hydraulic conductivity varies with pressure gradient and marks plant responses to injury. Plant Cell Environ. 2021, 44, 371-386. [CrossRef]

29. Hacke, U.G.; Sperry, J.S. Functional and ecological xylem anatomy. Perspect. Plant Ecol. Evol. Syst. 2013, 4, 97-115. [CrossRef]

30. Sperry J., S.; Hacke U., G.; Wheeler, J.K. Comparative analysis of end wall resistivity in xylem conduits. Plant Cell Environ. 2005, 28, 456-465. [CrossRef]

31. Schulte, P.J.; Hacke, U.G. Solid mechanics of the torus-margo in conifer inter-tracheid bordered pits. New Phytol. 2020, 229, 1431-1439. [CrossRef]

32. Schulte, P.J.; Gibson, A.C. Hydraulic conductance and tracheid anatomy in six species of extant seed plants. Can. J. Bot. Rev. Can. Bot. 1988, 66, 1073-1079. [CrossRef]

33. Qu, W.; Yang, C.; Ma, Y.; Yu, W.; Qin, G.; Jin, Y. Analysis of the Structure and Hydraulic Function of Bordered Pits Using the Lattice Boltzman Method. Forests 2021, 12, 526. [CrossRef]

34. Schoonmaker, A.L.; Hacke, U.G.; Landhäusser, S.M.; Lieffers, V.J.; Tyree, M.T. Hydraulic acclimation to shading in boreal conifers of varying shade tolerance. Plant Cell Environ. 2010, 33, 382-393. [CrossRef]

35. Brodersen, C.; Jansen, S.; Choat, B.; Rico, C.; Pittermann, J. Cavitation resistance in seedless vascular plants: The structure and function of interconduit pit membranes. Plant Physiol. 2014, 165, 895-904. [CrossRef]

36. Domec, J.C.; Lachenbruch, B.; Meinzer, F.C. Bordered pit structure and function determine spatial patterns of air-seeding thresholds in xylem of Douglas-fir (Pseudotsuga menziesii; Pinaceae) trees. Am. J. Bot. 2006, 93, 1588-1600. [CrossRef]

37. Schulte, P.J. Computational fluid dynamics models of conifer bordered pits show how pit structure affects flow. New Phytol. 2011, 193, 721-729. [CrossRef]

38. Schulte, P.J.; Hacke, U.G.; Schoonmaker, A.L. Pit membrane structure is highly variable and accounts for a major resistance to water flow through tracheid pits in stems and roots of two boreal conifer species. New Phytol. 2015, 208, 102-113. [CrossRef]

39. Bouche, P.S.; Larter, M.; Domec, J.C.; Burlett, R.; Gasson, P.; Jansen, S.; Delzon, S. A broad survey of hydraulic and mechanical safety in the xylem of conifers. J. Exp. Bot. 2014, 65, 4419-4431. [CrossRef]

40. Choat, B.; Cobb, A.R.; Jansen, S. Structure and function of bordered pits: New discoveries and impacts on whole-plant hydraulic function. New Phytol. 2008, 177, 608-626. [CrossRef]

41. Eskola, R.; Hämäläinen, J.; Leppänen, T. Finite element modeling of the effect of crossfield pits on the cell wall stress behavior. Nord. Pulp Pap. Res. J. 2012, 27, 647-652. [CrossRef]

42. Kim, D.H.; Kim, S.H.; Jo, J.I.; Kim, J.H.; Purusatama, B.D.; Lee, S.H.; Kim, N.H. Ray properties in the stems of Dahurian larch (Larix gmelinii) and Japanese larch (Larix kaempferi). IAWA J. 2020, 42, 134-142. [CrossRef]

43. Cochard, H.; Badel, E.; Herbette, S.; Delzon, S.; Choat, B.; Jansen, S. Methods for measuring plant vulnerability to cavitation: A critical review. J. Exp. Bot. 2013, 64, 4779-4791. [CrossRef] [PubMed] 